\title{
45. Seçili metinler bağlamında 15. yüzyıl tekke şiirinden örnek tasavvufî deyimler ile Allah, dünya, mürşit, derviş, ilahi aşk, masiva, tekke ve nefis kavramlarını ifade eden kelime ve kelime grupları ${ }^{1}$
}

Büşra KARASU²

\begin{abstract}
APA: Karasu, B. (2021). Seçili metinler bağlamında 15. yüzyll tekke şiirinden örnek tasavvufî deyimler ile Allah, dünya, mürşit, derviş, ilahi aşk, masiva, tekke ve nefis kavramlarını ifade eden kelime ve kelime grupları. RumeliDE Dil ve Edebiyat Araştırmaları Dergisi, (24), 771-792. DOI: 10.29000/rumelide.990196.
\end{abstract}

\section{$\ddot{O} \mathbf{z}$}

Türk kültürüne Arap ve Fars medeniyetlerinin tesiriyle girmiş olan tasavvuf, hemen hemen her alanda olduğu gibi edebiyatta da etkili olmuştur. Asırlar boyu kaleme alınan eserlerin büyük çoğunluğu kimi doğrudan kimi de dolaylı olmak üzere tasavvufî düşüncenin tesiri altında kalmıştır. Türkler arasında tasavvufî düşüncesinin gelişiminde tarih boyunca birçok önemli isim etkili olmuştur. Pîr-i Türkistan namıyla anılıp Yeseviyye tarikatının kurucusu olan Hoca Ahmed Yesevî bunlar arasındaki öncü şahsiyetlerdendir. Orta Asya'da tasavvufun teşekkülünde önemli bir rol üstlenen Ahmed Yesevî, birçok derviş yetiştirmiştir. Bu dervişler Anadolu'ya gelerek burada tasavvufun tekkeler vasıtasıyla yayılmasını sağlamışlardır. Dervişlerin hoşgörü, müsamaha, barış ve esenlik gibi kimi kavramları içeren söylemleri Türk halkına can suyu olmuştur. Böylelikle Yesevi dervişleri ve sonrasında Mevlana gibi farklı coğrafyalardan gelip Anadolu'da tasavvufî düşüncenin etkili olmasını sağlayan isimlerle birlikte Türk halkının tasavvufa teveccühü artmıştır. Sonrasında da bu düşünce sistemi, asırlar boyu Anadolu halkının dimağında yer edinmiştir. 15. yüzyıl da tasavvufun etkin olduğu dönemlerdendir. Bu yüzyılda çok sayıda eser kaleme alınmıştır. Bunlar arasında tasavvufî nitelikli olanlar da önemli bir yekûn tutmaktadır. Çalışmamızda öncelikle genel manada tasavvuftan, 15. yüzyl Tekke şiiri ve kavramlar ile deyimlerin kullanılışından bahsedilecektir. Ardından bu dönemde yazılmış eserler arasından seçmiş olduğumuz Kemâl Ümmî, Eşrefoğlu Rûmî, Kaygusuz Abdâl ve Dede Ömer Rûşenî divanları ile Süleyman Çelebi’nin Vesiletü’n-necât (Mevlid), Elvân-ı Şirâzî'nin Gülşen-i Râz Tercümesi, Hatiboğlu'nun Bahrü'l-Hakâyık'ı, Şeyh Eşref'in Nasîhatnâme'si ve Gülşenî-i Saruhânî'nin Râz-nâme'si bağlamında bu dönem Tekke edebiyatında tasavvufî mana içeren deyimler ile Allah, dünya, mürşit, derviş, ilahi aşk, masiva, tekke ve nefis kavramların ifade eden kelime ve kelime grupları üzerinde durulacaktır.

Anahtar kelimeler: Tekke, tasavvuf, deyim, terim, kavram

\section{In the context of selected texts sample mystical idioms from $15^{\text {th }}$ century Tekke poetry and the words and phrases that express the concepts of Allah, the world, the guide, the dervish, the divine love, the masiva, the lodge and the nafs}

\author{
Abstract \\ Sufism, which has entered Turkish culture with the influence of Arab and Persian civilizations, has \\ been influential in literature as well as in almost every field. The majority of the works written for \\ Bu makale, “15. Yüzyll Tekke Şiirinde Tasavvuf Terimleri” başlıklı yüksek lisans tezimizden geliştirilerek üretilmiştir. \\ (Karasu, 2018) \\ Arş. Gör., Bitlis Eren Üniversitesi, Fen Edebiyat Fakültesi, Türk Dili ve Edebiyatı Bölümü, Eski Türk Edebiyatı ABD (Bitlis, \\ Türkiye), bdinc@beu.edu.tr, ORCID ID: oooo-0003-3147-237X [Araştırma makalesi, Makale kayıt tarihi: 25.06.2021- \\ kabul tarihi: 20.09.2021; DOI: 10.29000/rumelide.990196] \\ Adres | Address \\ RumeliDE Dil ve Edebiyat Araşttrmaları Dergisi $\quad$ RumeliDE Journal of Language and Literature Studies \\ Osmanağa Mahallesi, Mürver Çiçeği Sokak, No:14/8 Osmanağa Mahallesi, Mürver Çiçeği Sokak, No:14/8 \\ Kadıköy - İSTANBUL / TÜRKIYE 34714 Kadıköy - ISTANBUL / TURKEY 34714 \\ e-posta: editor@rumelide.com e-mail: editor@rumelide.com, \\ tel: +90 505 7958124, +90 2167730616 phone: +90 505 7958124, +90 2167730616
}


In the context of selected texts sample mystical idioms from 15th century Tekke poetry and the words and phrases that express the concepts of Allah, the world, the guide, the dervish, the divine love, the masiva, the lodge and the nafs / B. Karasu (pp. 771792

centuries have been under the influence of mystical thought, some directly and some indirectly. Many important names have been influential in the development of mystical thought among Turks throughout history. Hodja Ahmed Yesevi, known as Pîr-i Türkistan and the founder of the Yeseviyye sect, is the leading figure among them. Ahmed Yesevi, who played an important role in the formation of Sufism in Central Asia, trained many dervishes. These dervishes came to Anatolia and ensured the spread of sufism here by means of lodges. The discourses of the dervishes, which include some concepts such as tolerance, peace and well-being, revived Turkish people. Thus, the Turkish people's favor towards sufism increased with the names of Yesevi dervishes and later Mevlana, who came from different geographies and enabled sufi thought to be effective in Anatolia. Afterwards, this system of thought has taken its place in the minds of the Anatolian people for centuries. The 15th century is also one of the periods when sufism was active. In this century, many works were written. Among them, the sufi-qualified ones hold an important part. In our study will be mentioned sufism in general, the $15^{\text {th }}$ century Tekke poem and the use of the concept and idioms. Then, the idioms containing mystical meanings in Tekke literature of this period in the context of the divans of Kemâl Ümmî, Eşrefoğlu Rûmî, Kaygusuz Abdâl and Dede Ömer Rûşenî, which we have selected among the works written in this period, as well as the Vesiletü'n-necât (Mevlid) of Süleyman Çelebi, the Translation of Gülşen-i Râz by Elvân-ı Şirâzî, Hatiboğlu's Bahrü'l-Hakâyı, Şeyh Eşref's Nasîhat-nâme and Gülşenî-i Saruhânî's Râz-nâme the words and phrases that express the concepts of Allah, the world, the guide, the dervish, the divine love, the masiva, the lodge and the nafs will be emphasized.

Keywords: Lodge, mysticism, idiom, term, concept

\section{Giriş}

Tasavvufî düşünce, İslam kültüründe ilk örneklerini Arap edebiyatında (Bilgin 2016: 25) vermiş olsa da Fars edebiyatına daha çok tesir etmiş ve edebî eserlere yansıması burada daha fazla olmuştur. Tasavvufî eserler, 11. ve 12. yüzyılda Fars edebiyatında hızla artmış, sonrasında başta Türk edebiyatı olmak üzere diğer edebiyatları da etkilemiştir. Tasavvuf düşüncesi, Türk kültüründe ilk olarak Orta Asya sahasında kendini göstermiştir. Tasavvufun Tanrı, varlık ve insan anlayışı zamanla dinî düşünceyi etkilemiş, kurulan tarikatlar vasıtasıyla bu durum toplumsal hayata da yansımıs ve neticesinde insanlara tasavvufu anlatmak için Türk edebiyatında çeşitli eserler yazılmaya başlanmıştır. Bunda tarikatların yadsınamaz bir etkisi olmuştur. Zira ilk olarak din adına gelişim göstermiş olan bu oluşumlar, daha sonraları kültür hayatında da kendine yer edinmiş, edebiyat da bunun önde gelen alanlarından olmuştur.

15. yüzyıl tasavvufun temsil edildiği, bu hususta birçok eserin kaleme alındığı ve tarikatların aktif olduğu bir dönem olmuştur. Bu devirde yüzyılın başlarındaki olumsuz siyasi gelişmeler edebiyata yansımamış (Şentürk - Kartal 2013: 201), Türk edebiyatı çeşitli mahfiller etrafında toplanan şairler vasıtasıyla gelişimini sürdürmüştür. Fetret Devri'nin sona ermesi ve Çelebi Mehmed'den sonra II. Murad'ın tahta çıkmasıyla Anadolu topraklarında kültürel faaliyetler bakımından önemli gelişmeler yaşanmıştır. İstanbul'un Fethi sonucu Osmanl Devleti'nin bir imparatorluğa dönüşmesiyle birlikte bu gelişmeler daha da artmış ve bu durum edebiyat sahasına da yansımıştır. Özellikle tekke ve tarikatlar etrafında şekillenen Tekke şiirindeki gelişmeler kayda değerdir. Toplumun her kesiminde etkili olup İstanbul'un manevi anlamda kurulmasına da öncülük etmiş olan tarikatlar (İnalcık (çev. İbrahim Kalın) 2004: 311) dinî-tasavvufî edebiyatın teşekkülü ve ilerlemesinde de temel saik olmuştur. Buna paralel olarak 15 . yüzyılda Tekke edebiyatı sahasında birçok isim yetişmiş ve gerek manzum gerek mensur ve gerekse de manzum-mensur olmak üzere çeşitli eserler kaleme alınmıştır. Divan sahibi şairlerden Kemâl Ümmî, Eşrefoğlu Rûmî, Kaygusuz Abdal ve Dede Ömer Rûşenî ile mesnevileriyle tanınan Süleymân Çelebî,

\footnotetext{
RumeliDE Dil ve Edebiyat Araştırmaları Dergisi Osmanağa Mahallesi, Mürver Çiçeği Sokak, No:14/8 Kadıköy - İSTANBUL / TÜRKIYE 34714 e-posta: editor@rumelide.com tel: +90 505 7958124, +90 2167730616 
Abdurrrahîm-i Rûmî, Yazıcıŏglu Mehmed, Ahmed Bican, İbrâhim Tennûrî, Elvân-ı Şirâzî, Muhyiddin, Pîr Muhammed, Muînî, Ârif, Ahmed Hayâlî bu yüzyılda dinî-tasavvufî edebiyat içerisinde değerlendirilebilecek eserler kaleme alan isimlerdendir.

Tasavvufun yüzyllar içerisinde kendine has bir dili oluşmuş, şiir de burada çok önemli bir görev üstlenmiştir. Zira "Tasavvuf, kendi terimlerini geliştirmeye başlarken sırrî ve özel yönünü korumak için mecazlarla örülü bir dil kullanmayı da sürdürmüştü. Şiir de bu sürece katkı sağlayan bir araç görevi görmüştür" (Demirli 2018: 17). Tasavvufun bu özel dili, 15. yüzyll Tekke şiirinin çalışmamız kapsamında yer alan metinlerinde de görülmektedir. Bu dönemde kaleme alınmış metinlerde tasavvufí terim, deyim ve kavramlarla süslenmiş metinlerin varlığı göze çarpmaktadır. Bu gelişme, tasavvufun Türk edebiyatına tesirinin başlangıcından bu devresine kadar olan gelişmeleri göstermesi ve kendinden sonraki yüzyıllarda kaleme alınmış olan eserlere tesiri bakımından oldukça mühimdir.

Çalışmamız dâhilinde 15. yüzyıl Tekke edebiyatında kaleme alınmış olan Kemâl Ümmî, Eşrefoğlu Rûmî, Kaygusuz Abdâl ve Dede Ömer Rûşenî divanları ile tasavvufî dil bakımından zengin veriler sunan Süleyman Çelebi'nin Vesiletü’n-necât (Mevlid)1, Elvân-ı Şirâzînin Gülşen-i Râz Tercümesi, Hatiboğlu'nun Bahrül-Hakâyık'ı, Şeyh Eşref Nasihatname'si ve Gülşenî-i Saruhânînnin Râz-nâme'si seçilerek metinlerden örnek tasavvufî deyimler ile Allah, dünya, mürşit, derviş, ilahi aşk, masiva, tekke ve nefis kavramlarını ifade eden kelime ve kelime grupları açıklanmıştır. Deyimlerin seçimi hususunda tasavvufî mana içermeleri göz önünde bulundurulmuş; incelenen metinlerde Allah, dünya, mürşit, derviş, ilahi aşk, masiva, tekke ve nefis gibi dinî-tasavvufî kavramların farklı kelime ve kelime gruplarıyla ifade edildiği göze çarpmış ve bunların tespiti yapılmaya çalışılmıştır.

\subsection{Yüzyıl tekke şiirinde tasavvufî manada kullanılan deyim örnekleri}

Türk Dil Kurumu Sözlüğ̈̈’nde, “Genellikle gerçek anlamından az çok ayrı, kendine özgü bir anlam taşıyan kalıplaşmış söz öbeği, tabir” olarak tanımlanan deyim, edebî metinlerin dil bakımından zenginleşmesini sağlayan önemli unsurlardandır. İsmail Parlatır tarafından da "En az iki söz varlığından oluşan ve gerçek anlamları dışında mecazî anlam ile pekiştirilmiş bulunan kalıplaşmış söz öbeği ya da deyiş" (Parlatır 2007: 1) şeklinde ifade edilen deyimleri, çeşitleri bakımlardan birkaç grupta değerlendirmek mümkündür. Bu gruplandırmayı yapan isimlerden biri olan Ömer Asım Aksoy'un kategorizasyonu şu şekildedir:

1. Kavramları, değişmece (mecaz) yoluyle, anlatım güzelliği ve özgünlüğü içinde belirten kalıplaşmış sözcük öbekleri ya da tümceler,

2. İki yargılı ve uyaklı deyimler,

3. Öykücük ve konuşma biçiminde deyimler,

4. Bir öykü ya da olaya dayanan deyimler,

5. Âdet, inanış ve gelenekleri bildiren deyimler,

6. Anlatım güzelliği düşünülmeden bir araya getirilen, kalıplaşmış söz öbeği şeklindeki deyimler,

7. Belli dil bilgisi kurallarıyla değil özel kalıplarla oluşturulan deyimler,

8. Eksiltili anlatım biçimiyle oluşan deyimler,

9. İkilemeler şeklinde oluşan deyimler,

10. Bir sözcüğün özel bir yardımcı eylemle kullanılmasıyla oluşan deyimler (Aksoy 1984: 404-414).

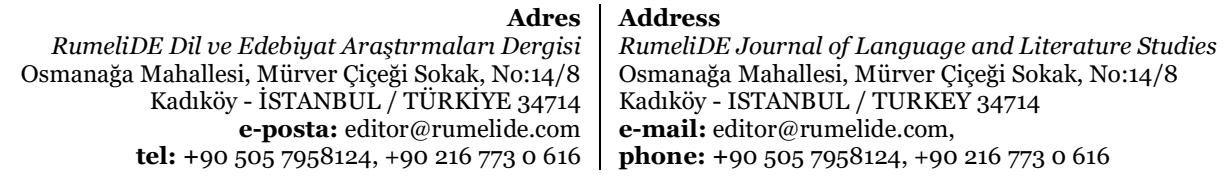

tel: +90 505 7958124, +90 2167730616 
In the context of selected texts sample mystical idioms from 15th century Tekke poetry and the words and phrases that express the concepts of Allah, the world, the guide, the dervish, the divine love, the masiva, the lodge and the nafs / B. Karasu (pp. 771792

15. yüzyll Tekke şiirinde tasavvufî manada kullanılan deyimlerin örnekleri incelendiğinde bunların "Kavramları, değişmece (mecaz) yoluyla, anlatım güzelliği ve özgünlüğü içinde belirten kalıplaşmış sözcük öbekleri ya da tümceler" ve "Bir sözcüğün özel bir yardımcı eylemle kullanılmasıyla oluşan deyimler” gruplarında yer aldığı söylenebilir. Zira bu deyimler mecaz yoluyla değişikliğe uğramış ve tasavvufî bir muhtevaya bürünmüşlerdir. Aynı zamanda bir yardımcı fiille beraber kullanılarak meydana gelmişlerdir.

İncelenen metinler içerisinden tasavvufî anlamları içermeleri sebebiyle seçilen deyimler şunlardır:

câna kalmak: tas.3 Allah yolunda benliğinden geçememek. "Cāna ḳalan 'āşık degül dost yolında șādlk degül / 'Āşsk kayuben cānına işini key düşvār ider [Allah yolunda benliğinden geçemeyen âşık değildir, dost yolunda (da) sadık değildir. Âşığın canına kıyması zor değildir.] 4 (ERD 35/4) 5

câna kıymak/cânına kıymak: "Öldürmek” (Parlatır 2007: 224) tas. Nefsini Allah yolunda öldürmek. "Cāna kalan 'āşsk degül dost yolında șādlk degül / 'Āşık kayuben cānına işini key düşsuār ider" [Allah yolunda benliğinden geçemeyen âşık değildir, dost yolunda (da) sadık değildir. Âşığın canına kıyması zor değildir.] (ERD 35/4)

cân oynamak/cânı oynamak: tas. İlahi aşk ile coşmak. "Yürek kaynar cān oynar bedende / Gönüul cūşı geçer haddan giderem" [(Bu) bedende yüreğim kaynar, canım ilahi aşk ile coşar. Gönül cuşa gelir, haddim hududum kalmaz. ] (ERD 76/10)

cân vermek: "Ölmek" (Kubbealtı Lugati) tas. Canını Allah yolunda feda etmek. "Nice cān vermeyem bu 'aş̧ yolına / Kul iken 'aşk beni sulțān idüpdür” [Bu aşk yolunda nasıl canımı vermeyeyim? Aşk beni kul iken sultan yapmaktadır.] (KAD g.15/5)

derde düşmek: Dertlenmek, dert sahibi olmak. tas. İlahi aşka tutulmak. "Derde düşmişdür yanar zārī ḳlur düni güni / Zārīsi ol dost firāạı bag̀rı biryān gizlidür” [Derde düşmüştür gece gündüz yanar inler (durur), inleyiş o dostun ayrılığı (sebebiyledir) bağrı kebap olmuştur.] (ERD 13/9)

derde sataşmak: Derde düşmek. tas. İlahi aşk ile hemhal olmak. "Bir derde sataşdum ki devā yāduma gelmez / Bir rence ulaşdum ki şifā yāduma gelmez" [Devası ve şifası yâdıma gelmez bir derde, bir zahmete düştüm.] (DÖR g. 29/1)

etek tutmak / el etek tutmak: tas. Bir şeyhe intisap edip tarikata bağlanmak, "Tasavvuf yoluna girmeyi ifade eden bir söz." (Cebecioğlu 2014: 145) "Anlardan ḳalmışdur bol erkān ușūl / Etegin

Açıklamalarda; BH: Bahrü’l-Hakâyık, DÖR: Dede Ömer Rûşenî Dîvânı, ERD: Eşrefoğlu Rûmî Dîvânı, GRT: Gülşen-i Râz Tercümesi, GSR: Gülşenî-i Saruhânî Râz-nâme’si, KAD: Kaygusuz Abdal Dîvânı, KÜD: Kemal Ümmî Dîvânı, g.: gazel, t.b. : terkib-bent, tas. : Tasavvufî mana kısaltmaları kullanılmıștır.

Mustafa Sever’in makalede esas alınan İznikli Eşrefoğlu Rûmî’nin Hayatı Eserleri ve Dîvânı eserinde şiirler nazım şekilleri belirtilmeden sıralandığı için makalede de nazım şekilleri belirtilmeden yalnızca şiir numaraları verilmiştir.

Calıșmada; Esrefoğlu Rûmî Dîvânı’ndan verilen örnek beyitlerde Mustafa Günes tarafından hazırlanan (Günes, Mustafa (2006). İznikli Eşrefoğlu Rûmînin Hayatı Eserleri ve Dîvânı. İstanbul: Sahhaflar Kitap Sarayı), Kaygusuz Abdal Dîvânı'ndan verilen örnek beyitlerde Mustafa Sever tarafından hazırlanan (Sever, Mustafa (2016). Dîvân-ı Kaygusuz Abdal, Ankara: Helke Yayıncılık), Dede Ömer Rûşenî Divanı'ndan verilen örnek beyitlerde Orhan Kemal Tavukçu tarafından hazırlanan (Orhan Kemal Tavukçu (2018) Dede Ömer Rûşenî Hayatı, Eserleri, Edebî Kişiliği ve Dîvânının Tenkidli Metni), Kemâl Ümmî Dîvânı'ndan verilen örnek beyitlerde Hayati Yavuzer tarafindan hazırlanan (Yavuzer, Hayati (1997). Kemâl Ümmî Dîvân İnceleme-Metin. Doktora Tezi. Ankara Gazi Üniversitesi), Gülşen-i Râz Tercümesi'nden verilen örnek beyitlerde Mehmet Malik Bankır tarafından hazırlanan (Mehmet Malik Bankır, Gülşen-i Râz (Gramer-Metin-Gramatikal İndeks), Atatürk Üniversitesi Sosyal Bilimler Enstitüsü Türk Dili ve Edebiyatı Anabilim Dalı, Erzurum, 1997), Süleyman Çelebi'nin Mevlid'inden verilen örnek beyitlerde Necla Pekolcay tarafından hazırlanan (Necla Pekolcay, Mevlid Süleyman Çelebi, Dergâh Yayınları, İstanbul, 2016.) çalıșmalar esas alınmıștır.

\section{Adres | Address}

RumeliDE Dil ve Edebiyat Araştırmaları Dergisi Osmanağa Mahallesi, Mürver Ciçeği Sokak, No:14/8 Kadıköy - İSTANBUL / TÜRKIYE 34714 e-posta: editor@rumelide.com

RumeliDE Journal of Language and Literature Studies Osmanağa Mahallesi, Mürver Çiçeği Sokak, No:14/8

Kadıköy - ISTANBUL / TURKEY 34714

e-mail: editor@rumelide.com,

tel: +90 505 7958124, +90 2167730616 phone: +90 505 7958124, +90 2167730616 
tutanlar olmışdur hāṣll / Ceddini sorarsañ Hazreti Resūl/ 'Abdü 'l-kādir sulțān dirler şeyhüme” [Erkan ve usul onlardan kalmıştır, (onun) eteğini tutanlara (bu) hasıl olmuştur. Ceddini sorarsan Hazret-i Resul'dür, Abdülkadir sultan derler benim şeyhime.] (ERD 113/2)

hevâya uymak: Heveslerine, isteklerine kapılmak. tas. Hak olanı terk edip nefsin arzu ve isteklerine uymak. "Hakkn koduñ sen hevāña uyduñ bir gün Hakka kul olmaduñ / Bende olduñ nefsüñe uyduñ olduñ putperest” [Hakk'ı (bir kenara) koydun, hevana uydun, bir gün Hakk'a kul olmadın. Nefsine bende olup ona uydun (sonunda) putperest oldun.] (ERD 61/6)

nefs basmak: tas. Nefsini alt etmek; ona galip gelmek. "Pehlüvān oldur bu meydān içre kim / Nefsini bașup ḳul ide aḳlhna” [Pehlivan, nefsini yenip onu aklına kul edendir.] (KÜD6 38/12)

satır çalmak / atmak: "Herkese öldüresiye saldırmak, herkesi kırıp geçirmek" (Parlatır 2007: 748), "Hepsini kırmak, kesip öldürmek" (Aksoy 1984: 867) tas. Nefis mücadelesinde bulunmak. "Giderler

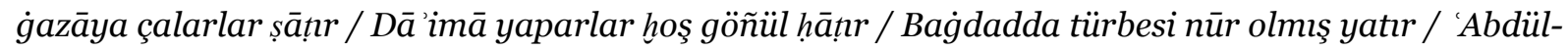
kādir sulțān dirler şeyhüme" [(Nefisle) gaza edip ona galebe çalarlar, (bu şekilde) hoş gönül hatır yaparlar. Abdülkadir Sultan dedikleri şeyhim Bağdat'taki türbesinde nur olmuş yatar.] (ERD 113/3)

\section{Allah, Dünya, mürşit, derviş, ilahi aşk, masiva, tekke ve nefis kavramlarını ifade eden kelime ve kelime grupları}

Arapça kökenli olan kelime, Kubbealtı Lugatı'nda “ Bir veya birkaç heceden meydana gelen anlamlı söz”, Türk Dil Kurumu Sözlüğü’nde de "Anlaml ses veya ses birliği, söz, sözcük, lügat” şeklinde tanımlanmıştır. Türkçe karşıllı̆̆ sözcüktür.

Kelime grupları ise metinler içerisinde farklı kavramları ifade ettiklerinde metni dil bakımından zenginleştiren, kelimelerin mana dünyasını farklı ifade biçimleriyle genişleten öğelerdir. Bunlar Muharrem Ergin tarafından "Tek bir nesneyi veya hareketi birlikte karşlayan kelimeler topluluğu" olarak nitelendirilmiştir. "Tekrarlar, bağlama grubu, sıfat tamlaması, iyelik grubu ve isim tamlaması, aitlik grubu, birleşik isim, birleşik fiil, unvan grubu, ünlem grubu, sayı grubu, edat grubu, isnat grubu, genitif, datif, ablatif grupları, fiil grubu, partisip grubu, gerundium grubu, kısaltma grupları ve akkuzatif grubu" (Ergin 2009: 374-398) şeklinde de sıralanmıştır. Zeynep Korkmaz da birleşik kelimeler bahsinde kelime gruplarının birleşik kelimelerde kullanılan söz kalıpları olduğunu söylemiştir (Korkmaz 2009: 137).

Bir şair yahut yazar tarafından nazmedilmiş bir metin kelime ve kelime grupları ile cümlelerden müteşekkildir. Sanatçılar eserlerinde dilin bu temel öğelerini kullanarak sanatlı ve edebî temayülü yüksek eserler meydana getirmişlerdir. Kimi zaman da birbirinin yerine sanatlı söyleyişler ile kullanılan kelimeler metnin dilini daha da zengin bir noktaya ulaştırmıştır. 15. yüzyl Tekke şiirinde kaleme alınan eserler incelendiğinde bu özelliğin Tekke şairleri tarafında da kullanıldığı görülmektedir. İncelenen eserler içerisinde yer alan dört divan ve beş mesneviye bakıldığında tasavvufun temel bazı kavramlarının metinler içerisinde farklı kelimeler ve kelime gruplarıyla ifade edildikleri dikkati çekmiş, bunların metinlerin dilinin zenginleşmesinde ve sanatlı söyleyişin hâkimiyetinin artmasında etkili olduğu saptanmıştır. Bu dönemde dinî-tasavvufî nitelikteki metinlerin meydana getirilmesi noktasında Allah, dünya, mürşit, derviş, ilahi aşk, masiva, tekke ve nefis kavramlarına karşıllk olarak farklı kelime ile

Hayati Yavuzer’in makalede esas alınan Kemâl Ümmî Dîvânı İnceleme-Metin isimli doktora tezinde şiirler nazım şekilleri belirtilmeden sıralandığı için makalede de nazım şekilleri belirtilmeden yalnızca şiir numaraları verilmiştir.

Adres | Address

RumeliDE Dil ve Edebiyat Araştırmaları Dergisi Osmanağa Mahallesi, Mürver Ciçeği Sokak, No:14/8 Kadıköy - İSTANBUL / TÜRKIYE 34714 e-posta: editor@rumelide.com

RumeliDE Journal of Language and Literature Studies Osmanağa Mahallesi, Mürver Çiçeği Sokak, No:14/8

Kadıköy - ISTANBUL / TURKEY 34714

tel: +90 505 7958124, +90 2167730616 phone: +90 505 7958124, +90 2167730616 
In the context of selected texts sample mystical idioms from 15th century Tekke poetry and the words and phrases that express the concepts of Allah, the world, the guide, the dervish, the divine love, the masiva, the lodge and the nafs / B. Karasu (pp. 771792

kelime gruplarının kullanıldığı tespit edilmiştir. Bu sebeple kavramlar için kullanılan kelime ve kelime gruplarını örnek beyitler ışığında göstermek ve bir tabloda bu kullanımları topluca değerlendirmek yerinde olacaktır.

\subsection{Allah için kullanılan kelime ve kelime grupları}

Allah kelimesinin etimolojisi hakkında çeşitli görüşler bulunmaktadır. Buna göre bir grup Allah kelimesinin yaratıcıya özel bir ad olduğunu ve herhangi bir kökten türemediğini ifade etmekte, diğer bir grup ise Allah kelimesinin ya "ilah" kökünden ya da gizlenmek manasına gelen "lâhe" kökünden geldiğini öne sürmektedir (Topaloğlu 1989: 500). Allah kelimesi dünya dillerinde Tanrı isimlendirmesiyle çeşitli şekillerde söylense de ilahi bir lafız olarak her zaman özel bir konumdadır. Bununla birlikte Allah’’n gerek diğer isimleri, gerek sıfatları ve gerekse de kendi özellikleri üzerinden O’nu tanımlayan çeşitli kelime ve kelime grupları oluşturulmuştur. Bunlar arasında 15. yüzyıl Tekke şiirinde çalışmamızın konusunu teşkil eden metinler bağlamındaki kullanımlar şunlardır:

bezm sultânı: tas. Elest bezminin sultânı olan Allah. "İrişmiş bezm sulțānına ol dem / Yaḳnlık hạşsıl itmiş şā $u$ hurrem" [Elest bezminin sultanı olan Allah'a eriştiğinde mutluydu, (kendisine) bir yakınlık hasıl olmuştu.] (GRT 2816.beyit)

bî-mekân: Yersiz, yeri yurdu olmayan. tas. Mekândan münezzeh olan Allah. "Zamānsuz bì-zamānam ben mekānsuz bì-mekānam ben / Dü 'ălemde hemānam ben benem her görinen gören" [Ben zamansız bizamanım, mekânsız bimekânım. İki cihanda da varım, görünen, gören (her şey) benim.] (ERD 85/14)

bî-zamân: Belli bir zamanla sinırlı olmayan. tas. Zamandan münezzeh olan Allah. "İ münezzeh pādişāh $u$ bì-zamān / İ mukaddes bì-nişān u bì-mekān [Ey belli zamana sığmamış, (her şeyden) münezzeh olan padişah! Ey belli bir nişanı ve mekânı olmayan mukaddes (olan Allah)!] (KÜD 7/2)

bî-nişân: İzi, belirtisi olmayan; alamete ihtiyacı olmayan. tas. Allah. "İ münezzeh pādişāh u bì-zamān / İ mukaddes bì-nişāan u bì-mekān [Ey belli zamana sığmamış, (her şeyden) münezzeh olan padişah! Ey belli bir nişanı ve mekânı olmayan mukaddes (olan Allah)!] (KÜD 7/2)

cân: Gönül, ruh. tas. Allah. "Tek göñül ol cānı bulsun n’ohsar / Tek göñül Allahı bulsun n'olısar" [Gönlüm yalnızca o canı bulsun ne olur? Gönlüm yalnızca Allah'ı bulsun ne olur?] (ERD 32/2)

cân-ı ebed lâ-yemût: tas. Varlığı baki olan, ölümsüz Allah. "Ben cān-ı ebed lāyemūtum / Perdem $\bar{a}$ dem oldı bār-ı takdīr" [Ben varlığının nihayeti olmayan (Allah'ım). (Benim) perdem (suretim) kaderin (kendisine) yüklediği (şekilde) insan oldu.] (KAD t.b.2/51)

cânân - cânâne: Sevgili, sevilen. tas. Allah. "Bir diñle aḥi hālüñi Kayg்usuz Abdāluñ / Cānı ḳoyuben ya 'nì ki cānānı gözledi” [Ey kardeşim! Kaygusuz Abdal'ın halini bir dinle. (O) canı(nı bir yana) koyarak Allah'ı istedi.] (KAD g.294/9)

dil-ârâ: Gönlü süsleyen güzel, sevgili. tas. Allah. "N’iderem şol dili ben kim söylemeye zikrün anuñ / N'iderem şol gözi ben kim ki görmeye dil-ārāyı" [O’nun zikrini söylemeyen dili ne yapayım? O sevgiliyi (Allah'ı) görmeyen gözü ne yapayım?] (ERD 130/10)

\begin{tabular}{r|l} 
Adres & Address \\
RumeliDE Dil ve Edebiyat Araştırmaları Dergisi & RumeliDE Journal of Language and Literature Studies \\
Osmanağa Mahallesi, Mürver Çiçeği Sokak, No:14/8 & Osmanağa Mahallesi, Mürver Çiçeği Sokak, No:14/8 \\
Kadıköy - İSTANBUL / TÜRKIYE 34714 & Kadıköy - ISTANBUL / TURKEY 34714 \\
e-posta: editor@rumelide.com & e-mail: editor@rumelide.com, \\
tel: +90 505 7958124, +90 216773 o 616 & phone: +90 505 7958124, +90 216773 o 616
\end{tabular}


dilber: Gönlü büyüleyen, kendine çeken sevgili (Steingass 1998:531). tas. Allah. "Cemālüñ Țūr-ı nūrından ey dilber / Baña her kande ki dursam Țūr old»” [Ey dilber! Cemalinin ışığının Tur Dă̆ı’ndan nerede dursam (orası) Tur Dağı oldu.] (KAD g.243/5)

dost: Arkadaş, âşık, seven. (Kanar 2011: 298) tas. Allah. "Altmış üç yaşa çün irdi ol Emīn / Dosta ulaşmaḳhigı oldı yakīn” [O Emin altmış yaşına erdiğinde Allah'a kavuşma vakti yaklaşmıştı.] (SVN 551. beyit)

habîb: Sevgili. tas. Allah. "Hevāsma bu nefsüñ uyma zinhār / Habīb rahm eylemez nefse uyana" [Nefsinin hevâsına zinhar uyma, (çünkü) Allah nefsine uyana merhamet etmez.] (ERD 98/9)

Hak: Allah. "Enbiyānuñ her birinüñ var nihāyet 'ilmine / Hak saña virdügi 'ilm ü hikmete yoh hadd ü 'add" [Nebilerin her birinin ilminin bir nihayeti vardır ama Allah'ın sana verdiği ilim ve hikmetin sınırı yoktur.] (DÖR g.6/4)

hakikat fâili: tas. Hakikatin yapıcısı, hakikat sahibi olan Allah. "Hakīkat fā 'ili sensin her işüñ / Ne zıdduñ ne şerīküñ var ne işüñ [Gerçekten her işin faili sensin. (Senin) ne zıddın ne şerikin ne eşin var.] (KÜD 1/2)

hoca: Efendi, usta, öğretmen. tas. Allah. "Saña yarın șormayısarlar nice / Yazdıyıdı saña levhüñnde Hoca” [Sana yarın (mahşer gününde) Allah’ın levh-i mahfuzda senin için (neyi) nasıl yazdığını sormayacaklar.] (ŞEN 295. beyit)

Hû: tas. Allah. "Kemāl Ümmī seni sen ḳo ana gitsin ki ḳala Hū / Çü birdir aña ġayr-ı ū hezārān biñ kemāl irmez” [Kemal Ümmi sen seni (bir kenara) koy ki (yalnız) Allah kalsın. Çünkü (O) birdir, O’ndan gayrısı kemale ermez.] (KÜD 3/27)

kâtib-i kudret: Kudret sahibi katip. tas. Allah. "Kātib-i kudret yazanda șafha-i haddüñde hațt / Şekl-i cìm itmiş külāleñ beñlerüñ itmiş nukāt”" [Allah yanağındaki hatları çizdiğinde (yanağına dökülen) saçının kıvrımlarını cim şeklinde, benlerini nokta nokta yapmış.] (DÖR g. 32/1)

lâ-mekân: Mekânı olmayan, mekâna sı̆̆mayan. tas. Mekândan münezzeh olan Allah. "Küllī cihān sevdāsım kodu elinden / Göñlüme bakıñ fikr ü hayāli lā-mekāndır" [Dünyadaki bütün sevdalardan elimi çektirdi. Gönlüme bakın fikri hayali mekânsız olan Allah’tır.] (KAD g.50/4)

ma'şūḳ: Âşık olunan, sevgili. tas. Allah. "Sūretüm 'âşık velī içüm țolu ma'şūk benüm / 'Āşık u ma'şūk u 'sşk birdür hemān kalma tan 'a” [Suretim âşıktır ama benim için sevgiliyle (Allah'la) doludur. Hemen (beni) ayıplama âşı, maşuk ve aşk (esasında) birdir.] (ERD 1/5)

Mevlâ: Sahip, efendi. tas. Kainatın efendisi olan Allah. "N'olur ise ko ki olsun n'olssar / Tek göñül Mevlāyı bulsun n'olısar” [Bırak ne olacaksa olsun yalnı,, gönül Mevla'yı bulsun. ] (ERD 31/1)

mey-fürûş: Şarap satan, aşk şarabı satan. tas. Allah. "Zerk ü riyā țarīkine harc etmeyem ‘ömrümü ben / Mey-fürūşa kulluk idem koyam bu menzilden geçem” [Ben ömrümü iki yüzlülük ve riya yoluna vermeyip Allah’a kulluk edeyim, bu menzilden (de bu şekilde) geçeyim.] (KAD g.127/7)

nakkâş: Nakış ustası, nakış işleyen, nakış yapan (Parlatır 2006: 1257). tas. Allah. "Nakkāaşa țapan nakşa șapup renge kapılmaz / Ma şūḳ seven ġayrını kor kim bu sivādur” [Nakkaş’a (Allah’a) tapan

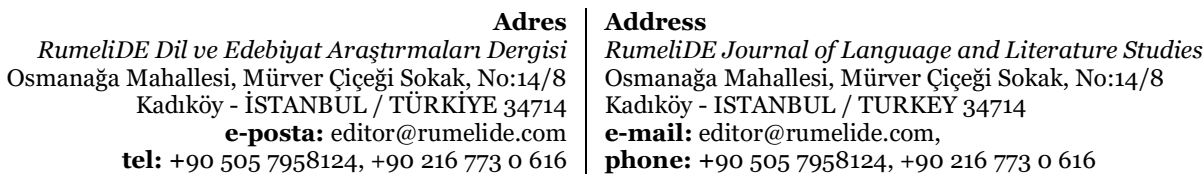


In the context of selected texts sample mystical idioms from 15th century Tekke poetry and the words and phrases that express the concepts of Allah, the world, the guide, the dervish, the divine love, the masiva, the lodge and the nafs / B. Karasu (pp. 771792

nakşa sapıp renge kapılmaz. Sevgiliyi (Allah’’) seven ondan gayrısını masiva olduğu için bir kenara brrakır.] (KÜD 139/3)

pâdişâh: Hükümdar. tas. Allah. "Dahı hem rahmeti var pādişāhuñ / Ki ol dermānıdur derdüñ ve āhuñ” [(O) Padişah’ın rahmeti vardır, (O) dert ve ahın dermanıdır. (BH varak: 30-A 11. satır)

pâdişâh-ı bî-niyâz: Yalvarmayan, yalvarmaya ihtiyacı olmayan padişah. tas. Hiç kimseden yardım istemeye muhtaç olmayan Allah. "Bilürem pādişāh-ı bì-niyāzsın / Saña yalvaranı maḥrūm ḳomazsm" [Hiç kimseye niyaz edecek durumda olmayan padişah olduğunu, sana yalvaranı (rahmetinden) mahrum bırakmayacağını bilirim.] (ERD 4. münacat 5. satır)

pâdişâh-ı bî-zevâl: Zeval bulmayacak, varlığı devamlı olacak padişah. tas. Varlığı ebedi olan Allah.

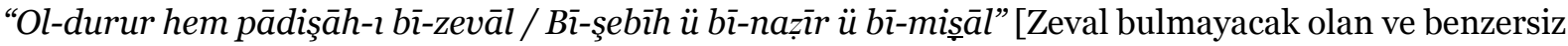
padişah O’dur. ] (SVN 23)

pâdişâh-ı yektâ: Eşi benzeri olmayan padişah. tas. Allah. "Vāhid ü Șamed ü Ahad pādişāh-ı yektā / Kadīr ü Kāim ü Rahmō̄n Kerìm ü Ferd ü Vedūd” [Vahid, Samed, Ahad, Eşsiz padişah, Kadir, Kaim, Rahman, Kerim, Ferd ve Vedud (olan Allah)...] (KAD g.11/6)

pâdişâhlar pâdişâhı: tas. Padişahlar padişahı olan Allah. "Pādişāhlar pādişāhı hażreti / Șora senden incidürseñ bir iti” [Padişahlar padişahı (olan) Allah bir köpeği (dahi) incitsen (onu) senden sorsun.] (ŞEN 69. beyit)

sâkî: İçki sunan. tas. İlahi aşk şarabı sunan Allah. "Temāşā bāḳ̄ vü dīdār bāḳ̄ / Şarāb u 'iş̧ bāḳ̄ rabb sāḳ̂” [Bakış baki, (sevgilinin) yüz(ü) baki, şarap ve zevk baki, Rab saki...] (GRT 1918. beyit)

sâkî-i bâkî: Beka sahibi olan saki. tas. Allah. "Ben ol șāḳ̂̄i bākīnüñ elinden / İçerim cām-ı meyi dilşādım ben" [Ben meyi o bekası olmayan sakinin elinden içerim, gönlüm (bu sebeple) şaddır.] (KAD g.155/2)

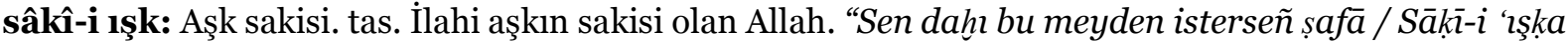
ser ü cān it feda" [Sen de bu meyden mutluluk bulmak istersen aşkın sakisine kendini feda et.] (GSR 950)

sultân: Hükümdar. tas. Allah. "Ayır nefsüñi şeytāndan ki strlar tuyasın cāndan / 'Atālar gele sulțāndan yakīne ire gümānuñ” [Can (u gönülden) sirlar duymak, Allah'tan sana hediyeler gelmesi (ve) şüpheden slyrılıp yakîne ermek için nefsini şeytandan ayır.] (ERD 58/12)

sultân-ı ekber: En büyük sultan. tas. Allah. "Te ālellāh zihī sulțān-ı ekber / Ki ḳıldı sözini dilde mu 'attar" [Tealallah en büyük sultan (olan Allah) sözünü dilde hoş kokulu kıldı.] (BH varak: 24-A, 5 . satır)

şâh - şeh: Padişah, hükümdar. tas. Allah. "Biz ölümlü ḳul i Şeh sen bekāssn / Dilerüz rahmetüñ ile bakasın” [Ey şah! Biz ölümlü kullarız sense varlığının sonu olmayansın. (Bize) rahmetin ile bakmanı dileriz.] (KÜD 1/82)

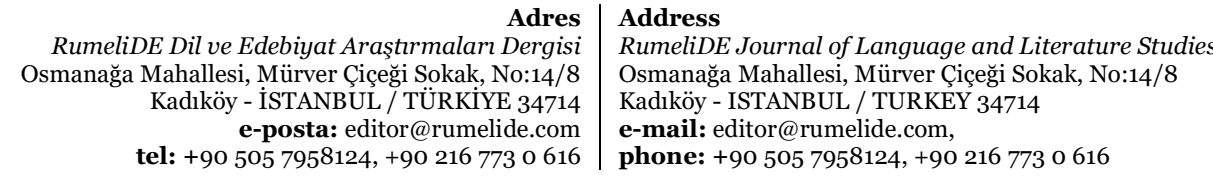


Seçili metinler bağlamında 15. yüzyll tekke şiirinden örnek tasavvufî deyimler ile Allah, Dünya, mürşit, derviş, ilahi aşk, masiva, tekke ve nefis kavramlarını ifade eden kelime ve kelime grupları / B. Karasu (771-792. s.)

\begin{tabular}{|c|c|}
\hline & bezm sultânı \\
\hline & bî-mekân \\
\hline & bî-nişân \\
\hline & bî-zamân \\
\hline & cân \\
\hline & cân-ı ebed lâ-yemût \\
\hline & cânân/cânâne \\
\hline & dil-ârâ \\
\hline & dilber \\
\hline & dost \\
\hline & habîb \\
\hline \multirow{11}{*}{ Allah } & Hak \\
\hline & hakîkat fâili \\
\hline & hoca \\
\hline & Hû \\
\hline & kâtib-i kudret \\
\hline & lâ-mekân \\
\hline & ma'şūk \\
\hline & Mevlâ \\
\hline & mey-fürûş \\
\hline & nakkâş \\
\hline & pâdişâh \\
\hline
\end{tabular}

\section{Address}

RumeliDE Journal of Language and Literature Studies

Osmanağa Mahallesi, Mürver Çiçeği Sokak, No:14/8

Kadıköy - ISTANBUL / TURKEY 34714

e-mail: editor@rumelide.com

tel: +90 505 7958124, +90 2167730616 phone: +90 505 7958124, +90 2167730616 
In the context of selected texts sample mystical idioms from 15th century Tekke poetry and the words and phrases that express the concepts of Allah, the world, the guide, the dervish, the divine love, the masiva, the lodge and the nafs / B. Karasu (pp. 771792

\begin{tabular}{|l|l|}
\hline & pâdişâhlar pâdişâhı \\
\cline { 2 - 2 } & sâkî̀ \\
\cline { 2 - 3 } & sâkî-i ışk \\
\cline { 2 - 3 } & sultân \\
\hline & sultân-ı ekber \\
\hline & şâh/şeh \\
\hline & yâr \\
\hline
\end{tabular}

Tablo 1: Allah İçin Kullanılan Kelime ve Kelime Grupları Tablosu

\subsection{Dünya kavramı için kullanılan kelime ve kelime grupları}

Kur'an-ı Kerim'de dinî ve ahlakî bir terim şeklinde kullanılıp kozmik anlamından ziyade yeryüzünde devam ettirilen yaşantının kastedildiği dünya kelimesinin kökeni hususunda çeşitli görüşler bulunmaktadır. Bunlara göre dünya yakın olmak manasındaki "dünüv” yahut alçaklık anlamındaki “denâet”den türemiştir (Uludağ 1994: 22). Kökeni hususunda bu görüşler olan dünyaya, tasavvufta kulu Allah’tan alıkoyan her şey, ahiretin tarlası, imtihan yeri ve geçici âlem yakıştırmaları yapılmıştır (Cebecioğlu 2014: 135). Dinî - tasavvufî metinlerde de tasavvuftaki izahlarına paralel olarak dünya çeşitli kelime ve kelime gruplarıyla ifade edilmiştir. 15. yüzyıl Tekke şiirinde çalışmamız kapsamında bulunan metinlerde de bu örneklere rastlamak mümkündür.

cîfe: Kokmuş ceset, leş. tas. Dünya. “Ol Haḳk Habībi Muștafā bu dünyāya cîfe didi / O ki ussı olan kişi cīfeye aldanur degül [O Hak Habibi Mustafa bu dünyaya leş dedi. Aklı başında olan (kişi) bu dünyaya aldanmaz.] (ERD g. 67/6)

derbend: Geçit. tas. Ahiret geçidi olan, kulu maddi zevklere sürükleyen dünya. "Bu derbendi geç Eşrefog̀lı Rūmī / İriş kāfileye sālārı gözle” [(Bir geçit olan) bu dünyayı geç Eşrefoğlu Rumi, kafileye eriş, kafile reisini gör.] (ERD 101/9)

fâni 'âlem: Geçici âlem. tas. Dünya. "Cihān cîfe-i gergeslere vir / Bu fānī 'ālemi nā-keslere vir" [Cihanı akbabaların leşine ver, bu fani âlemi de kimsesiz olanlara ver.] (GRT 2551. beyit)

fâni ev: Geçici ev, barınak. tas. Dünya. "Ādemīseñ ol bekā mülkinde ur bünyāduñ̃ / Kașruñı bu fāni evde yapma mișl-i 'ankebūt [(Gerçek manada bir) insansan ahirette yurt edin, kasrını örümcekler gibi geçici olan bu dünyada kurma.] (KÜD 41/6)

fâni mülk: Geçici memleket. tas. Dünya. "Bu fāni mülke baka bilen bāḳ̄ bilmedi / Șoñ yurdı gözedür şu ki 'ibret gözin açar" [Şu geçici mülke, dünyaya bakan baki olanın ne olduğunu bilmez (fakat) ahireti gözeten (kişi) ibret gözünü açar.] (KÜD 48/2) 
fenâ: Geçici olan, baki olmayan. tas. Dünya. "Bu fenāya sen neden böyle gönül virdüñ̃iy yār / İy 'aceb düşmez mi hergiz önüne o bāḳ yār" [Bu fenaya (geçici olan dünyaya) sen neden böyle gönül verdin ey yar? O baki yar (Allah) hiç mi aklına düşmez?] (ERD 19/1)

gel-geç evi: tas. Geçici hayatın meskeni olan dünya. "Bu cihān gel-geç evidir bāḳ̄ kalmaz kimseye / Cemşīdün 'akh dükenir hükkm-i Süleymān geçer” [Bu cihan gel-geç evidir, ebediyen kimseye kalmaz. (Sonunda) Cemşid'in aklı tükenir de Süleyman'ın hükmü geçer.] (KAD g. 68/4)

harâbât: Harabe, meyhane. tas. Dünya. "Bu ḩarābātuñ niçün mi 'mārr olam çünki ben / Dostrla ḳldum ezelde 'ahd ü peymān giderem” [Ben neden bu harabatın (dünyanın) mimarı olayım? Ben ezelde dosta yeminler ettim, (ona) gidiyorum.] (ERD 79/6)

hâristân: Dikenlik. tas. Zorluklarla, mücadelelerle dolu dünya. "Şu bülbülem ki gülden ayru düşdüm / Fìrāḳyla bu hāristāna geldüm” [Gülümden ayrı düşmüş (bir) bülbülüm. (Onun) ayrıllğı ile bu haristana (dünyaya) geldim.] (ERD 73/3)

kârbân-saray (kervân-sarây): Kervanların konaklaması için yapılan vakıf yapıları. tas. İnsanların konup göçtüğü yer; dünya. "Bu vīrān kārbansarāyda cāy u mesken tutma kim / Kimseye bekāsı yokdur ḳu ölür sulțān geçer" [Bu viran kervansarayda (dünyada) mesken edinme çünkü (dünyanın) kimseye bekalık sunduğu yoktur. Kul ölür, sultan geçer...] (KAD g. 68/2)

köprü: tas. Dünya. Dünyaya üzerinden gelip geçilen ve nihayetinde sona erecek olan bir köprü olduğuna dair hadis-i şerif olduğu rivayet edilen dinî bir söylemden dolayı bu yakıştırma yapılmıştır. "Buña gönül baġlayup mağrur olup kalmak neden / Çünki bu bir köpridür gelen geçer ḳlmaz karār" [Buna gönül bağlayıp, mağrur olarak kalmak neden? (Bu dünya) bir köprüdür, (buradan) gelen geçer (kimse bunda) karar kllmaz.] (ERD 19/3)

sûret âlemi: tas. Görünüş âlemi; dünya. "Geç bu sūret 'āleminden gir ma‘ānī mülkine / Seyr idüp strlar tuyasın seb 'a'-i seyyareden” [Yedi gezegeni seyredip (ondan) sırlar duymak için bu suret âleminden geç, mana mülküne gir.] (ERD 92/8)

\begin{tabular}{|c|c|}
\hline \multirow{11}{*}{ Dünya } & âlem \\
\hline & cîfe \\
\hline & derbend \\
\hline & fâni ‘âlem \\
\hline & fâni ev \\
\hline & fâni mülk \\
\hline & fenâ \\
\hline & gel-geç evi \\
\hline & harâbât \\
\hline & hâristân \\
\hline & kârubansaray/kervansaray \\
\hline $\begin{array}{r}\text { Adres } \\
\text { RumeliDE Dil ve Edebiyat Arassttrmaları Dergisi } \\
\text { Osmanağa Mahallesi, Mürver Çiçeği Sokak, No:14/8 } \\
\text { Kadıköy - İSTANBUL / TÜRKIYE } 34714 \\
\text { e-posta: editor@rumelide.com } \\
\text { tel: +90 505 7958124, +90 216 } 773 \text { o } 616\end{array}$ & $\begin{array}{l}\text { Address } \\
\text { RumeliDE Journal of Language and Literature Studies } \\
\text { Osmanağa Mahallesi, Mürver Çiçeği Sokak, No:14/8 } \\
\text { Kadıköy - ISTANBUL / TURKEY } 34714 \\
\text { e-mail: editor@ @umelide.com, } \\
\text { phone: +90 505 7958124, +90 } 216773 \text { o } 616\end{array}$ \\
\hline
\end{tabular}


In the context of selected texts sample mystical idioms from 15th century Tekke poetry and the words and phrases that express the concepts of Allah, the world, the guide, the dervish, the divine love, the masiva, the lodge and the nafs / B. Karasu (pp. 771792

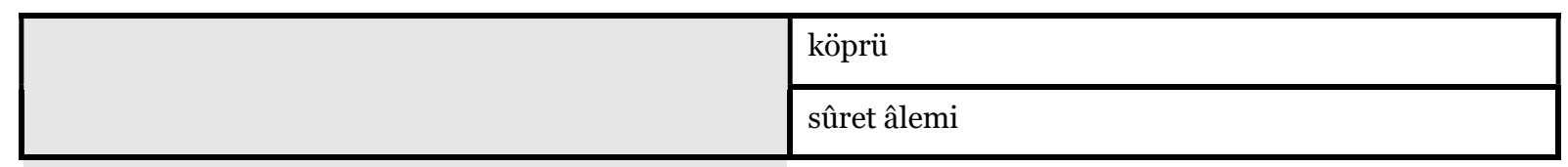

Tablo 2: Dünya kavramı için kullanılan kelime ve kelime grupları tablosu

\subsection{Mürşit kavramı için kullanılan kelime ve kelime grupları}

Doğru yol göstermek manasındaki "irşad” kelimesinden türemiş olan mürşid "rehber, kllavuz" anlamlarına gelmektedir (Kubbealtı Lugatı). Kelime "veli ve pîr kelimeleriyle eş anlamlıdır" (Öngören 2010: 50), tasavvufî bir terim olarak da "Sırat-ı müstakimi gösteren, dalâletten önce hak yola ileten" (Uludağ 2012: 263) kimse manasına gelmektedir.

Anlamsal çerçevesi bu şekilde olan kelime, metinler içerisinde bu tanımlar dişında başka kelime ve kelime gruplarıyla da ifade edilmiştir. Kavramın 15. yüzyll Tekke şiirinde seçilmiş olan metinler bağlamındaki görünümü şu şekildedir:

kulavuz-kılaguz-kulaguz: Yol gösteren, rehber. tas. Mürşit. "Gerekdür yolda kulavuz ki sālik menzil alavuz / Aña kimse ḳulavuzsuz muhāl ender muhāl irmez” [Salikin menziline ulaşması için kılavuz gereklidir, ona kimse kılavuzsuz eremez.] (KÜD 3/23)

ma'nâ eri: tas. Mana sırrına eren kişi; mürşit. "Ma 'nā erinüñ deminde (ger) ḩiżmet ederseñ / Toldur koynunu ḳlmayasın ma nā ile boş" [Mana eri (olan mürşit) için hizmet edersen koynunu mana ile doldur, boş kalma.] (KAD g. 87/6)

pîr: Yaşlı kimse. tas. Yol gösteren rehber, mürşit. "Sahnn kadḥ itmegil pīrüñ elüñden gelse medh eyle / Ki pīrüñ her ki kadh eyler mürīd iken merīd olur" [Sakın arkasından kötü söz etme, elinden geldiğince pirini öv. Çünkü pirini çekiştiren (kişi) mürit iken başkaldıran, serkeş kimse olur.] (DÖR g. 8/2)

pîr-i mugân: tas. Mürşid-i kâmil. "Etegin dutuban pīr-i muġānuñ / Kơdı lezzzetlerin cān u cihānuñ" [(Bir) mürşid-i kâmilin eteğini tutarak nefsinin ve cihanın (tüm) lezzetlerini bıraktı.] (GRT 2302. beyit)

sâkî: tas. İlahi aşkı müritlerine sunan mürşit. "Bu sāḳ̄̄den nice ‘āşık-ı sermest / İçiben cān gözin yırtdı hicābl” [Bu sakiden nice sermest âşık (ilahi aşk şarabını) içerek can gözüyle utanma duygusunu bıraktı.] (KAD g.244/8)

şeyh: Yaşlı kimse. tas. Taliplere yol gösteren Hak dostu kimse (Uludağ 2012: 334). "Şeyhi dilinden cevāb eydür size / Kend’özinden söylemez Ümmī Kemāl” [Kemal Ümmi kendisi söylemez, şeyhinin dilince cevap verir size.] (KÜD 86/33)

\begin{tabular}{|l|l|}
\hline \multirow{4}{*}{ Mürşit } & kulavuz/klaguz/kulaguz \\
\cline { 2 - 2 } & mánâ eri \\
\cline { 2 - 2 } & pîr \\
\cline { 2 - 2 } & pîr-i mugân \\
\cline { 2 - 2 } & sâkî̀ \\
\hline
\end{tabular}


şeyh

Tablo 3: Mürşit Kavramı için Kullanılan Kelime ve Kelime Grupları Tablosu

\subsection{Derviş kavramı için kullanılan kelime ve kelime grupları}

Kökeni hakkında çeşitli görüşler ileri sürülmekle birlikte Farsça olarak bilinen derviş kelimesi yoksul, dilenci, muhtaç anlamlarına gelmektedir. Kelime ilk dönemlerden itibaren Arapça zâhid ve fakîr kelimelerinin karşılı̆̆ı olarak kullanılmıştır (Yazıcı 94: 188). Bunun yanı sıra tasavvufî bir terim olarak da sufi demektir (Gevherîn h. 1388/m. 1968: 607- 5. cilt).

Kelime, bahis konusu olan metinler içerisinde 15. yüzyl Tekke şiirinde şu kelime ve kelime gruplarıyla anılmıştır:

abdâl: tas. Derviş; gayb erenleri. "Sayıları yedi, yetmiş ya da kırk olarak gösterilen bir evliya zümresi." (Uludağ 2012: 19) "Gör Kayg்usuzu abdāl olup şeydā vü mecnūn / Şāh eşiğiniñ hāk-i pāyında karār eyler" [Kaygusuz’u gör, abdal olup çıldırmıştır. Şah eşiğinin ayağının toprağında karar eylemiştir.] (KAD g. 60/11)

âşık: Çok seven, âşık olan, seven. tas. "İlahi aşka düşmüş kimse” (Parlatır 2017: 94) “Āşılkssañ teni terk it cānı ko cānāna git / Tene cāna kalanuñ işi hacālet tā ebed" [(Eğer) âşıksan bedeninden geç, canını bir yere koy, canana git. Vücuda, bedene takılıp kalanın işi ebediyete kadar utanmaktır.] (ERD 4/3)

aşk bülbülü:7 İlahi aşkı şakıyan bülbül. tas. Derviş. “Iş̧̧ana düşen cānlaruñ yolına baş virenlerüñ / 'Işsk bülbüli olanlaruñ kimse dilin bilmez imiş" [Aşskna düş̧en canların, yoluna can verenlerin, aşk bülbülü olanların kimse dilini bilmezmiş.] (ERD 45/4)

aşk elçisi: tas. İlahi aşkın elçisi. "Bu 'ş̧k elçisi vahdet meşrebinde / Gönüullere gelür Hakk'dan nidādur" [Vahdet meşrebinde bu aşk elçisi Hak’tan gönüllere gelen nidadır.] (KAD g.19/5)

aşk eri: Aşk adamı. İlahi aşk yolunda olan; derviş, salik. "Eyyūb gibi șabr eyle belādan iñleme zinhār / 'Iş̧ eri belā zehrini șabrıla şeker ḳlur" [Eyüp gibi sabret, asla beladan (dolayı) inleme. Aşk eri bela zehrini sabır ile şeker kılar.] (ERD 27/7)

aşk tâciri: Aşkın ticaretini yapan, aşk satan kimse. tas. Derviş. "Sefer ḳlur vücūdından bu 'ş̧kuñ tāciri dā'im / İrer bāzārına 'ış̧uñ virür bir cāmı biñ cāna” [Bu aşk taciri dima varlığından sefer kılıp aşkın pazarına erer ve bir canını bin cana verir.] (ERD 99/7)

bülbül: “Karatavukgillerden, sesinin güzelliği ile tanınmış olan ötücü kuş” (TDK Güncel Türkçe Sözlük) tas. Hakikat bağının bülbülü olan derviş. "Ben ol dost baġçesinün bülbüliyem / İlāhī bülbüli gülden ayırma" [Ben o dost bahçesinin bülbülüyüm (şeyhin tekkesindeki bir dervişim). İlahi! Bülbülü gülden ayırma. ] (ERD 112/5)

Așk kelimesi incelenen metinlerin bazılarında așk, bazılarında ıșk șeklinde yazılmıștır. Makalede madde başlıklarında kelimenin aşk şeklinde yazımı tercih edilmiş, metin içerisinde verilen örnek beyitlerde alıntılanan kaynaktaki yazım aynen aktarılmıștır. 
In the context of selected texts sample mystical idioms from 15th century Tekke poetry and the words and phrases that express the concepts of Allah, the world, the guide, the dervish, the divine love, the masiva, the lodge and the nafs / B. Karasu (pp. 771792

fakîr: Yoksul. tas. Kendini Allah’a muhtaç bilen kimse; derviş (Uludağ 2012: 131). "Karār itdi fak̄ir buldı mekānı/N'ider ol zerre içün buldı kānı” [Fakr (derviş) mekânını bulup (onda) karar kıldı. Zerreyi ne yapsın o (hazinenin) kaynağını buldu.] (BH varak: 55-A, 6 satır)

gavvâs: Dalgıç. tas. İlahi aşk denizine dalan derviş. "'Gavvāṣum bu baḥr içinde bunca zamāndan berü / Șarrāfum söyle ki gelsün gevher ü kān bulmuşam” [Bunca zamandır bu deniz içinde (bir) dalgıcım. Sarrafıma söyleyin gelsin bir cevher ve kaynak buldum.] (KAD g. 124/3)

Hak dostu: tas. Allah dostu, Allah yolunda olan. "Dervīşler Haḳkuñ dostı cānları ezel mesti / 'Işsk şem 'ini yakdılar pervāne olan gelsün” [Dervişler Hakk'ın dostudur, canları ezelden sarhoştur. (Onlar) aşk mumunu yaktılar, pervane olan gelsin.] (ERD 86/9)

miskîn: Zavallı, âciz. tas. Derviş. "Çü șūfilik șafā vü meskenetdür / Kudūret mi olur miskīn içinde" [Sufilik safa ve meskenettir. Miskinin içinde (buna dair) şüphe mi olur?] (KÜD 119/2)

sarrâf: "Altın, mâdenî ve kâğıt paraları birbiriyle değiştirmeyi, bozmayı, tahvil alış verişi yapmayı meslek edinmiş kimse" (Kubbealtı Lugatı) tas. Derviş. "Șārrāfum makșūdum ya ni șadefdür / Hak̄ikat dürr ü gevherni tiler men" [Sarrafım, maksudum sedeftir. Ben hakikat incisi ve cevherini dilerim.] (KAD g.153/4)

şâhbâz: Doğan. tas. Derviş. "Pes yine maḥrem olmaġa şāha bir şāhbāz gerek / Yokssa degme ḳuş avını alup şāha varur degül” [Şaha yakın mahrem olmak için şahbaz gerek, yoksa her kuşla şaha varmak mümkün değildir.] (ERD 67/8)

uzlet ehli: tas. Halk içinde Hak'la olan derviş. “'Uzlet ehlidür seven hem sevilen / Sen bu 'uzletden kaçarsın pes neden” [Seven de sevilen de uzlet ehlidir. Sen bu uzletten neden kaçarsın?] (ERD pendname 3/5)

\begin{tabular}{|c|c|}
\hline \multirow{13}{*}{ Derviş } & abdâl \\
\hline & âşık \\
\hline & bülbül \\
\hline & fakîr \\
\hline & gavvâs \\
\hline & Hak dostu \\
\hline & aşk bülbülü \\
\hline & aşk elçisi \\
\hline & aşk eri \\
\hline & ak tâciri \\
\hline & miskîn \\
\hline & sarrâf \\
\hline & şâhbâz \\
\hline $\begin{array}{r}\text { Adres } \\
\text { RumeliDE Dil ve Edebiyat Arasstrtrmalart Dergisi } \\
\text { Osmanağa Mahallesi, Mürver Çiçeğ Sokak, No:14/8 } \\
\text { Kadıköy - İTANBUL / TÜRKIYY } 34714 \\
\text { e-posta: editor@rumelide.com } \\
\text { tel: +90 505 7958124, +90 } 216773 \text { o } 616\end{array}$ & $\begin{array}{l}\text { Address } \\
\text { RumeliDE Journal of Language and Literature Studies } \\
\text { Osmanağa Mahallesi, Mürver Çiçeği Sokak, No:14/8 } \\
\text { Kadiköy - ISTANBUL / TURKEY 34714 } \\
\text { e-mail: editor@ rumelide.com, } \\
\text { phone: +90 505 7958124, +90 } 216773 \text { o } 616\end{array}$ \\
\hline
\end{tabular}


uzlet ehli

Tablo 4: Derviş kavramı için kullanılan kelime ve kelime grupları tablosu

\section{5. İlahi aşk kavramı için kullanılan kelime ve kelime grupları}

Kelime manası itibariyle şiddetli arzu ve sevgi manasına gelmektedir. Aşkı bir tasavvuf bir de Divan edebiyatında olmak üzere iki kısımda ele almak mümkündür (Pala 2018: 38). Ulvi olana yani Allah’a yönelik olan aşk, ilahi aşktır. O, İslami edebiyat içerisinde “aşk-ı hakîkî, aşk-ı ilâhî ve mutlak aşk”tır (Parlatır 2017: 96). Bu kavram metinlerde farklı kelimelerle ifade edilmiştir:

bâde-i câm-ı ezel: Ezel kadehinin içkisi. tas. İlahi aşk. "Bāde-i cām-ı ezelden mest olupdur şöyle kim / 'Ammā tendür nūrı mest ü nārr mest” [Ezel kadehinin içkisi olan ilahi aşktan öyle bir mest olmuştur ki (onun) ışı ̆̆ı, ateşi, teni hep sarhoştur (artık o, tüm varlığıyla ilahi aşkın sarhoşu olmuştur).] (KAD g. $8 / 8)$

bahr-i bî-pâyân: Sonu, nihayeti olmayan deniz. tas. İlahi aşk, ilahi aşk denizi. "Bu deryādan bular çıkardı dürri / Olar girdi bu baḥr-i bì-pāyāna” [Bunlar uçsuz bucaksız denize girerek denizden inciyi çıkardı.] (ERD 98/23)

aşk-1 hakîkî: tas. Hakiki, ilahi aşk. "Anı sevmekdürür 'ışk-ı ḥakīḳ̄ / Kalanuñ sevgüsi nefs ü hevādur" [Hakiki aşk onu sevmektir, kalanın sevgisi (ise) nefsani arzu ve hevestir.] (KÜD 50/11)

muhabbet - mahabbet: "Sevgi, aşk" (Pala 2018: 329) "Mahabbet olara arada muhakkak / Hakuñ ola vü ol anuñ ola Hak” [Onların arasında muhakkak muhabbet vardır. O Allah'ındır, Allah onundur.] (GRT 2055)

şarâb: İçki, içecek. tas. İlahi aşk, "Sâlikin ilâhî aşkı yoğun ve sürekli biçimde yaşaması" (Uludağ 2010: 269). "Ol şarābı kim ben içdüm fārig̀-i peymāneden / Șākisi ol bāki yüzdür cehd idüp iriş aña” [Ben o şarabı (her şeyden el etek çekme) kadeh(inden) içtim. Bu şarabı sunan kişi baki olan Allah’tır, nefsinle mücadele edip O’na eriş.] (ERD 1/3)

\begin{tabular}{|l|l|}
\hline \multirow{4}{*}{ İlahi Aşk } & âb-ı hayvân \\
\cline { 2 - 2 } & bâde-i câm-ı ezel \\
\cline { 2 - 2 } & bahr-i bî-pâyân \\
\cline { 2 - 2 } & aşk-ı hakîkî \\
\cline { 2 - 2 } & muhabbet \\
\cline { 2 - 2 } & şarâb \\
\hline
\end{tabular}

Tablo 5: İlahi aşk kavramı için kullanılan kelime ve kelime grupları tablosu

\subsection{Masiva kavramı için kullanılan kelime ve kelime grupları}

“Sözlükte 'şey' anlamına gelen mâ ile 'başka, gayr' anlamındaki sivâ kelimesinden türetilmiş” (Uludă̆ 2003: 76) olan masiva, "tasavvufta Allah dışında kalan her şeydir" (Cebecioğlu 2014: 320). Kelimenin çalışma kapsamındaki metinlerde yer alan farklı kullanım biçimleri şu şekildedir:

\footnotetext{
RumeliDE Dil ve Edebiyat Araștırmaları Dergisi Osmanağa Mahallesi, Mürver Ciçeği Sokak, No:14/8 Kadıköy - ISTANBUL / TÜRKIYE 34714 e-posta: editor@rumelide.com tel: +90 $5057958124,+902167730616$

Address

RumeliDE Journal of Language and Literature Studies

Osmanağa Mahallesi, Mürver Çiçeği Sokak, No:14/8

Kadıköy - ISTANBUL / TURKEY 34714

e-mail: editor@rumelide.com,

phone: +90 505 7958124, +90 2167730616
} 
In the context of selected texts sample mystical idioms from 15th century Tekke poetry and the words and phrases that express the concepts of Allah, the world, the guide, the dervish, the divine love, the masiva, the lodge and the nafs / B. Karasu (pp. 771792

gayr: Başka, diğer. tas. Allah dışında kalan şey; masiva. "Tapmaz ol ma 'būd u makșūdı bilen ġayriye

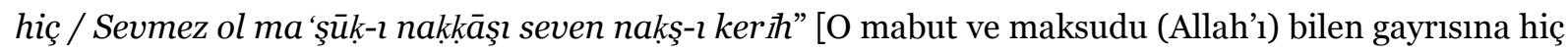
tapmaz. O sevgiliyi seven dünyanın tiksindirici uğraşlarını sevmez.] (KÜD 6/6)

gayr-1 Hak: Hakk’’n dışındaki şeyler. tas. Masiva. “Ġayr-ı Hak kalbine bulmaz idi yol / Şöyle kim Hak ‘ş̧-ile tolmışdı ol” [Allah dışında kalanlar (onun) kalbine yol bulmazdı, o Hak aşkı ile dolmuştu.] (SVN 433)

gayr-ı Mevlâ: Allah'ın dışındaki şey. tas. Masiva. "Vücūdum içinde doġru bak bir / Kimdir daḩ de kim gayr-ı Mevlā” [Vücudum içine bir bak (da) Allah’tan gayrısı kimdir söyle.] (KAD terci'-bend 2/82)

sivâ: Diğer, başka. tas. Masiva; "Hakk’ın gayri kabul edilen varlıklar" (Uludağ 2003: 76). "Nakkāş̧a țapan nakşa șapup renge kapılmaz / Ma şūḳ seven ġayrın kor kim bu sivādur” [Nakkaş'a (Allah’a) tapan nakşa kayıp renge kapılmaz. Sevgiliyi (Allah’ı) seven ondan gayrısını masiva olduğu için bir kenara birakır.] (KÜD 139/3)

\begin{tabular}{|l|l|}
\hline \multirow{4}{*}{ Masiva } & fenâ \\
\cline { 2 - 2 } & gayr \\
\cline { 2 - 2 } & gayr-1 Hak \\
\cline { 2 - 2 } & gayr-1 Mevlâ \\
\cline { 2 - 2 } & sivâ \\
\hline
\end{tabular}

Tablo 6: Masiva kavramı için kullanılan kelime ve kelime grupları tablosu

\subsection{Tekke kavramı için kullanılan kelime ve kelime grupları}

"Aynı tarikata bağlı kişilerin bir araya geldikleri, mürşidleriyle beraber barındıkları mimari kuruluşlar" (Tanman - Parlak 2011: 370)a tekke denilmektedir. Farsça metinlerde bu kelime yerine dergâh ve hankah kullanılmıştır (Kara 2011: 368). Tekke için çalışmamızda bahis konusu olan metinlerde çeşitli yer tanımlamaları yapılmıştır. Bunları şu şekilde sıralamak mümkündür:

dost bağçesi: Dost bahçesi. tas. Tekke. "Biz ol bülbüllerüz dost bāġçesinde / Seyrāna gelmişüz bu gülistāna" [Biz o dost bahçesinin (tekkenin) bülbülleriyiz, bu gülistanı seyran etmeye geldik.] (KAD g.236/6)

harâbât: Meyhane. tas. Tekke. "Cānumda nakss olan göñlimde torlak / Benüm sermāye dükkānum harābāt” [Canımda nakşolan gönlümde torlaktır. Bütün sermayem, dükkânım harabattır.] (KAD g.2/6)

harâbât-hâne: Meyhane. tas. Tekke. "Harābāthānede kulluk idelden / Halloldu külli müşkilim harābāt" [Harabathanede (tekkede) hizmet ettiğimden beri bütün zor işlerim halloldu (ey) harabat.] (KAD g.4/2)

harâbât-1 mugân: Meyhanecilerin meskeni. tas. Mürşidin tekkesi. "Mutasavviflar harâbâtı bir tekke olarak ele alırlar ve orada ilâhî aşk şarabının içilip sarhoş olunduğunu söylerler." (Pala 2018: 192) "Bu harābāt-ı muḡānda oluben mest-i müdām / Bāde-i şevḳi içüp itme gerek cūş u hurūşs” [Bu tekkede insanı cezbeye getiren ilahi aşk şarabını içerek sarhoş olmak ve coşmak gerekir.] (DÖR k.4/9)

\begin{tabular}{r|l} 
Adres & Address \\
RumeliDE Dil ve Edebiyat Araştırmaları Dergisi & RumeliDE Journal of Language and Literature Studies \\
Osmanağa Mahallesi, Mürver Çiçeği Sokak, No:14/8 & Osmanağa Mahallesi, Mürver Çiç̧ı Sokak, No:14/8 \\
Kadıköy - İSTANBUL / TÜRKIYY 34714 & Kadıköy - ISTANBUL / TURKEY 34714 \\
e-posta: editor@rumelide.com & e-mail: editor@rumelide.com, \\
phone: +90 505 7958124, +90 2167730616
\end{tabular}


aşk mey-hânesi: Aşk meyhanesi. tas. Tekke. "Ṭaşradan zāhid-i ḩod-bīn ne bilür ležzzetini / 'Işk meyhānesi içinde olan gulġulenüñ [Kendini beğenmiş zahit dışarıdan aşk meyhanesinde olan sesin (şarap seslerinin) lezzetini ne bilsin.] (DÖR g.42/5)

mey-hâne: Şarap evi. tas. Tekke. “Geldüm bu mey-ḩānede esrar yiyem şarāb içem / Serḩoş olam bekri bigi bu zühd ü sālūsdan geçem” [Bu meyhaneye esrar yiyip şarap içmeye, sarhoş olup zühd ve riyakârlıktan geçmeye geldim.] (KAD 127/1)

\begin{tabular}{|l|l|}
\hline \multirow{5}{*}{ Tekke } & dost bağçesi \\
\cline { 2 - 2 } & harâbât \\
\cline { 2 - 2 } & harâbât-hâne \\
\cline { 2 - 2 } & harâbât-ı mugân \\
\cline { 2 - 2 } & aşk mey-hânesi \\
\cline { 2 - 2 } & mey-hâne \\
\hline
\end{tabular}

Tablo 7: Tekke kavramı için kullanılan kelime ve kelime grupları tablosu

\subsection{Nefis kavramı için kullanılan kelime ve kelime grupları}

Arapça kökenli olan nefis; can, ruh, öz varlık gibi anlamlara gelmektedir. Kelimenin tasavvufta kazandığı terim anlamı "kulun kötü huyları ve çirkin vasıflarıdır" (Uludağ 2012: 274). Kûşeyrî̀ye göre, "Sûfîler nefs sözünü kullandıkları zaman bu kelime ile ne bir şeyin varlığını (vücûd) ne de va’z olunmuş kalıbı (cismi) kastederler, onların nefs kelimesinden muradı, kulun kötü (ve illetli) vasıfları ile yerilen (ve zemm edilen) huy ve fiilleridir" (Kuşeyrî (haz: Uludağ): 2019: 181). İncelenen metinler içerisinde nefs kavramı bu kelime dışında benlik ve cân kelimeleriyle de ifade edilmiştir.

benlik: tas. İnsanın egosu, nefsi, nefsani arzuları. "Dost yüzin göstermeyen bildüm ki benlükmiş baña / Benlik evin yıkdum yakdum çün ‘imāret itmezem” [Bana dost yüzünü göstermeyen şeyin, kendi nefsim ve egolarım olduğunu anladım. Benlik evini yaktım yıktım, (artık onu) imaret etmem.] (ERD 72/10)

cân: Ruh, iç âlemi. tas. Varlık, nefis. "Cānlular varmaz bu yola cānum diyen yolda kala / Cān terk iden doṣtı bula cāndan sefer itmek gerek" [Nefsine bakan kimseler bu yola varmaz, nefsini ön planda tutan yolda kalır. Nefsini terk eden, ondan geçen dostu bulur nefisten sefer etmek (onu yenmek) gerek.] (ERD $56 / 7)$

\begin{tabular}{|l|l|}
\hline \multirow{2}{*}{ Nefis } & benlik \\
\cline { 2 - 2 } & cân \\
\hline
\end{tabular}

Tablo 8: Nefis kavramı için kullanılan kelime ve kelime grupları tablosu

\section{Değerlendirme}

15. yüzyıl Tekke edebiyatı ve bu dönemde tasavvufî kavramların kullanımına dair tespitleri içeren çalışmamızda Kemâl Ümmî, Eşrefoğlu Rûmî, Kaygusuz Abdâl ve Dede Ömer Rûşenî divanları ile Vesiletü’n-necât (Mevlid), Gülşen-i Râz Tercümesi, Bahrü’l-Hakâyık, Nasîhat-nâme ve Râz-nâme

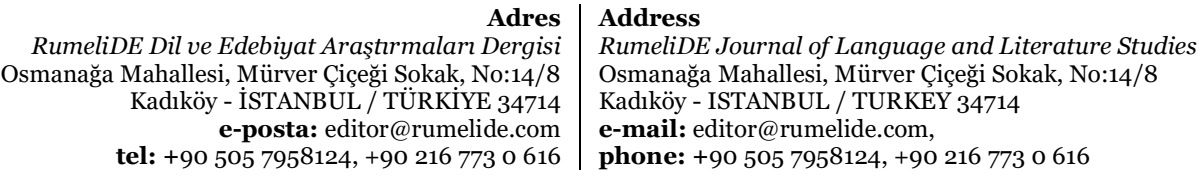


In the context of selected texts sample mystical idioms from 15th century Tekke poetry and the words and phrases that express the concepts of Allah, the world, the guide, the dervish, the divine love, the masiva, the lodge and the nafs / B. Karasu (pp. 771792

mesnevileri olmak üzere toplam dokuz metin incelenmiştir. Bu eserler içerisinden seçilip çalışmada anlam ve örneklerine yer verilen deyimler; câna kalmak, câna kıymak/cânına kıymak, cân oynamak/cânı oynamak, cân vermek, derde düşmek, etek tutmak/el etek tutmak, hevâya uymak, , nefs basmak ve satır çalmak/atmak'tır. Metinlerde deyimler iki gruba ayrılmaktadır. Bunlardan ilki, dinî bir söylem ile tasavvufî bir nitelik kazandırılan deyimlerdir. Canâ kıymak/cânına kıymak, cân vermek, derde düşmek, derde sataşmak, hevâya uymak ve satır çalmak bunlardandır. Bu deyimler mecaz yoluyla oluşmuştur. "Kelimenin lafzı ile mânası arasındaki alâka üzerine kurulmuş edebî sanatların en çok rağbet edileni” (Uzun 2003: 221) olan mecaz sayesinde deyimler, asıl anlamlarından çıkarak tasavvufî bir mana yüklenmişlerdir. İkinci grup ise doğrudan tasavvufî anlam ifade eden deyimlerdir. Etek tutmak/el etek tutmak, hevâya uymak ve nefs basmak bu grupta yer almaktadır.

İncelenen divanlarda Allah, dünya, mürşit, derviş, ilahi aşk, dünyalık hevesler, masiva, tekke ve nefis kavramlarının farklı kelime ve kelime gruplarıyla ifade edildiği görülmüsstür. Metinlerde bu minvalde Allah için bezm sultân, bî-mekân, bî-nişân, bî-zamân, cân, cân-ı ebed lâ-yemût, cânân/cânâne, dilârâ, dilber, dost, habîb, Hak, hakikat fâili, hoca, Hû, kâtib-i kudret, lâ-mekân, ma 'şûk, Mevlâ, meyfürûş, nakkâş̧, pâdişâh, pâdişâhlar pâdişâhl, sâkî, sâkî-i ışk, sultân, sultân-ı ekber, şâh/şeh ve yâr ifadeleri kullanılmıştır. Allah için kullanılan kelime veya kelime grupları incelendiğinde bunların Allah'ın isim ve sıfatları ile kendisine nispet edilen birtakım nitelikler üzerinden yapılan benzetmeler olduğu göze çarpmaktadır. Bunlar arasında Hak, Hû ve Mevlâ Allah'ın isimleri; bî-mekân, bî-nişân, bîzamân ve lâ-mekân Allah'in sıfatlarıdır. Bezm sultânı, pâdişâhh, pâdişâhlar pâdişâhı, sultân, sultân-ı ekber, şâh/şeh Allah'ın kâinatın sultanı olması hasebiyle O'na yakıştırılan niteliklerdir. Cân, cân-ı ebed lâ-yemût, cânân/cânâne, dil-ârâ, dilber, dost, habîb, ma'şûk ve yâr kelimeleri sevgili için kullanılan ifadelerin tasavvufî nazarda hakiki sevgili için sarf edilmesine örnektir. Bunlar dışında bir iş yapan, bir işi yerine getiren kimseler için kullanılan kelimelerden olan hakikat fâili, hoca, kâtib-i kudret, meyfürûs, nakkâş, sâkî ve sâkî-i ışk ise dinî-tasavvufî bir bakışla Allah'ı tanımlar bir hale gelmiştir. Örneğin bunlar içinde nakkâş kelimesinin gerçek anlamı süsleme ustası iken sözcük mecazî olarak kâinatı süsleyen, bezeyen, şekil veren Allah anlamını kazanmıştır.

Metinlerde dünya için âlem, cîfe, derbend, fâni 'âlem, fâni ev, fâni mülk, fenâ, gel-geç evi, harâbât, hâristân, kârubansaray/kervansaray, köprü, sûret âlemi ifadeleri kullanılmış olup bunlar dünyanın harap olmuş, kötü, geçici bir konaklama yeri olduğu düşüncesi üzerinden oluşturulmuştur. Bu kelimeleri kullanan şairlerin zihnî arka planında bu fikir mevcuttur. Âlem, cîfe, derbend, fâni âlem, fâni ev, fâni mülk, fenâ, gel-geç evi, harâbât, hâristân, kârubansaray/kervansaray, köprü, sûret âlemi ifadelerinin tümü bu şekildedir. Bu ifadelerin arasında cîfe, derbend, harâbât, hâristân ve kârubansaray/kervansaray istiare yoluyla dünya kavramını ifade etmiştir. Dünyanın kötülügünü, haraplığını ifade eden kullanımlar ise olumsuz anlamlarıyla metinlerde yer almıştır. Köprü kelimesi ise hadis olduğu rivayet edilen, "Dünya bir köprüdür, ondan geçiniz ama onu onarmayını" (Yılmaz 2013: 90) sözünden iktibastır.

Mürşit için kullanılan kulavuz/kılaguz/kulaguz, ma'nâ eri, pîr, pîr-i mugân ve sâkî ifadelerinde onun yaşlı, yol gösterici ve kılavuz olduğu dile getirilmiştir. Bu ifadelerin içerisinde kulavuz/kılaguz/kulaguz, pîr ve pîr-i mugân doğrudan mürşidin eş anlamlısıdır. Mainâ eri ve sâkî ise bunların dışındadır. Burada sâkî kelimesi istiare sanatı yoluyla mecazî anlamda kullanılmakta, bu yolla mürşit ilahi aşkın dağıtıcısı olan kimse anlamına gelmektedir. Ma'nâ eri ise tasavvufta "hakikat, sır, marifet" (Uludağ 2012: 236) anlamında ma'na ile "velî, ermiş" (Kubbealtı Lugati) manasındaki er kelimelerinin isim tamlamasıyla bir araya gelmesi sonucu oluşmuştur. Bu ifade hakikat sırrına ermiş kimse ve hakikat adamı anlamıyla mürşidin tasavvuf yolunda oluşunu kelime bazında doğrudan ifade etmektedir.

RumeliDE Dil ve Edebiyat Araştırmaları Dergisi Osmanağa Mahallesi, Mürver Çiçeği Sokak, No:14/8 Kadıköy - İSTANBUL / TÜRKIYE 34714 e-posta: editor@rumelide.com tel: +90 $5057958124,+902167730616$
Address

RumeliDE Journal of Language and Literature Studies

Osmanağa Mahallesi, Mürver Çiçeği Sokak, No:14/8

Kadıköy - ISTANBUL / TURKEY 34714

e-mail: editor@rumelide.com,

phone: +90 5057958124 , +90 2167730616 
Abdâl, âşık, bülbül, cân, fakîr, gavvâs, Hak dostu, aşk bülbülü, aşk elçisi, aşk eri, aşk tâciri, miskin, sarrâf, şâhbâz, tarîkat sâlik ve uzlet ehli derviş kavramının metinler içerisindeki farklı ifade biçimleridir. Bunlar arasında ilk olarak dervişin aşk bülbülü, aşk elçisi, aşk eri ve aşk tâciri örneklerinde görüleceği üzere aşk ile birlikte ifade edildiği göze çarpmaktadır. Bu kelimelerde dervişin ilahi aşkın tüccarı, elçisi, bülbülü ve mensubu olduğu söylenmiştir. Âşık ve fakîr kelimeleriyle dervişlerin ilahi aşk ve fakr sahibi kişiler olduğu vurgulanmıştır. Hak dostu, aşk eri, uzlet ehli ve miskîn ifadeleriyle de dervişin bizatihi tasavvuf ehli olduğu dile getirilmiştir. Dervişin bülbül, aşk bülbülü ve şâhbâz örneklerinde olduğu gibi bazı hayvanlara benzetilerek kullanılmış olması da dile getirilmesi gereken bir husustur. Bu kullanımlarda derviş bülbül ile ilahi hakikati şakımaktadır. Şahbaz yani doğan olarak da cesur ve atik bir şekilde ilahi aşk yolunda ilerlemektedir. Burada esasen şahbaz benzetmesiyle dervişlerde tembellik anlamındaki miskinlik ve bezginlik olmaması gerektiğinin altı da çizilmiştir. Zira bu minvalde Eşrefoğlu Rûmî̀nin de belirttiği üzere şaha şahbaz, Allah’a şahbaz nitelikli derviş kullar yaraşmaktadır: "Pes yine maḥrem olmag̉a şāha bir şāhbāz gerek / Yoḳsa degme ḳuş avını alup şāha varur degül” (ERD 67/8)

İlahi aşkın âb-ı hayvân, bâde-i câm-ı ezel, bahr-i bî-pâyân, aşk-ı hakîkî, muhabbet ve şarâb şeklinde ifade edildiği metinlerde bu kavram daha çok ilahi aşk şarabı olarak düşünülerek içecek ya da denize benzetilmiştir. Âb-ı hayvân, bâde-i câm-ı ezel, bahr-i bî-pâyân ve şarâb örnekleri bu minvaldedir. Aşkı hakîkî ve muhabbet kullanımları ile de ilahi aşk ve hakiki muhabbet olarak görülmüştür.

Masivanın ifade ediliş biçimlerinde kelimenin Türkçede başka, diğer anlamlarına gelen sivâ ve daha çok sivânın eş anlamlısı olan gayr ile birlikte kullanıldığı görülmektedir. Gayr, gayr-ı Hak ve gayr-ı Mevlâ bunlara örnektir. Masiva bunun dışında fenâ olarak da anılmıştır. Burada fenâ ifadesi masivanın yani Allah dışında kalan her şeyin geçiciliğinden mülhem olarak kullanılmış, özelde de esasen geçici olan her şeyin dünyada olması sebebiyle dünyayla benzeştirilmiştir.

Tekke bu devir şairlerinin dilinde dost bağçesi, harâbât, harâbât-hâne, harâbât-ı mugân, aşk meyhânesi ve mey-hâne şeklinde ifade edilmiştir. Kavram bu tanımlamalarda dost bağçesi ile bahçeye, harâbât, harâbât-hâne, harâbât-ı mugân, mey-hâne ve aşk mey-hânesi ile meyhaneye benzetilmiştir. Bu kelime ve kelime gruplarıla manevi anlamda ilahi feyiz yeri olup bu manada daha çok soyut bir anlamı ihtiva eden tekkeler somutlaştırılarak dile getirilmiştir. Burada özellikle meyhanenin tercih edilmesinde tıpkı kilise kelimesinde olduğu gibi (Şimşek 2017: 91) klasik şiir telakkisinde buraların da tekke, dergâh ve zaviyelerin aksine hakikati temsil eden yerler olarak görülmüş olması etkilidir.

Metinlerde nefis için eş anlamlı karşllık olarak Türkçe benlik ve Farsça asıllı ruh, iç âlem, gönül manalarındaki cân kelimeleri kullanılmıştır. Benlik nefs kelimesinin doğrudan Türkçe karşılığı ve eş anlamlısıdır. Kelime, metinlerde Arapça Farsça kimi kavramların Türkçeleştirilmesine örnek olması akımından önemlidir. Cân ise bir mecâz-ı mürsel örneğidir, insanın varlığının içsel boyutunu temsil etmekte ve nefs kavramı için kullanıldığında bu iç âlemin olumsuz taraflarını ifade etmektedir.

\section{Sonuç}

Kemâl Ümmî, Eşrefoğlu Rûmî, Kaygusuz Abdâl ve Dede Ömer Rûşenî divanları ile Süleyman Çelebi’nin Vesiletü̉n-necât (Mevlid)1, Elvân-ı Şirâzînin Gülşen-i Râz Tercümesi, Hatiboğlu'nun BahrülHakâyık', Şeyh Eşref'in Nasîhat-nâme'si ve Gülşenî-i Saruhânî'nin Râz-nâme'si bağlamında 15. yüzyıl Tekke şiirinde yer alan tasavvufî manadaki deyimler ile Allah, dünya, mürşit, derviş, ilahi aşk, masiva, tekke ve nefis kavramlarını ifade eden kelime ve kelime grupları üzerinde durulan çalışmamızda

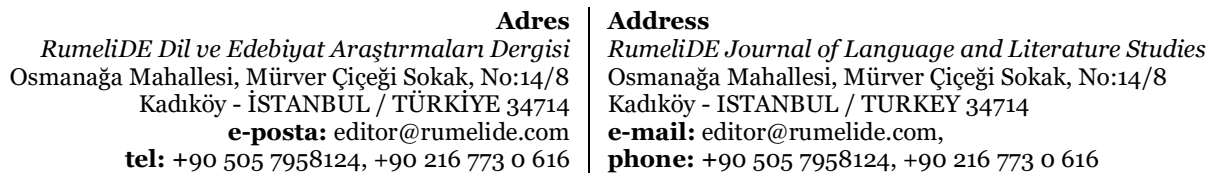


In the context of selected texts sample mystical idioms from 15th century Tekke poetry and the words and phrases that express the concepts of Allah, the world, the guide, the dervish, the divine love, the masiva, the lodge and the nafs / B. Karasu (pp. 771792

tasavvufî deyimler ile Allah, dünya, mürşit, derviş, ilahi aşk, masiva, tekke ve nefis kavramlarını ifade eden kullanımlar metinlerden seçilen örnek beyitler eşliğinde açlklanmıştır. Deyimler ve kavramları ifade eden kelime ve kelime gruplarının oluşum şekillerine bakıldığında büyük kısmının söz sanatlarının özellikle de mecazın ve onun türü olan istiarenin imkânlarıyla oluşturulduğu görülmüştür. Mecazlarda deyim ya da kavramların tasavvufî nitelik kazanması için dinî-tasavvufî bir söylem oluşturulmuştur. Ayrıca kavramın olumlu ya da olumsuz anlamlar içermesine bağlı olarak kelime seçimlerinin yapıldığı ve bunda anlam dünyasının da etkili olduğu fark edilmiştir. Bu hususta örneğin dünya kavramının geçiciliği ve ahirete nispetle harap ve fenâ bir yer olması gibi özellikleri hasebiyle dünya için cîfe, derbend, fâni âlem, fâni ev, fâni mülk, fenâ, gel-geç evi gibi karşllılar verilmiştir. Metinlerde kavramların ve deyimlerin Türkçeleştirilerek ifade edilmesi konusunda da birkaç örnek görülmektedir. Nefis için kullanılan benlik ile fani dünya anlamında kullanılan gel-geç evi kullanımları bu noktada dile getirilebilir. Ayrıca satır çalmak deyiminin de “mücâhede”nin bir karşılığı olduğu söylenebilir.

\section{Kaynakça}

Aksoy, Ömer Asım (1984). Atasözleri ve Deyimler Sözlüğü. Ankara: Türk Tarih Kurumu.

Ay, Mahmut - Erdem, Engin (2019). İlahiyat Terimleri Sözlüğü. Ankara: Grafiker.

Bankır, Mehmet Malik (1997).Gülşen-i Râz (Gramer-Metin-Gramatikal İndeks), Erzurum, Atatürk Üniversitesi Sosyal Bilimler Enstitüsü Türk Dili ve Edebiyatı Anabilim Dalı, 1997.

Baydar, Arzu Sema Ertane ve Turgut Baydar (2001). “Türkiye Türkçesinde Kelime Grupları”. Atatürk Üniversitesi Türkiyat Araştırmaları Dergisi. S. 16.

Bilgin, A. Azmi (2011). “Tekke Edebiyatı”. Türkiye Diyanet Vakfi İslam Ansiklopedisi. C. 40.

Bilgin, A. Azmi (2007). “Türk Tasavvuf Edebiyatı Literatürü”. Türkiyat Araştırmalar Literatür Dergisi. C. 5 , S. 10.

Bilgin, A. Azmi (2016). Türk Tasavvuf Edebiyat Makaleleri. Ankara: Türk Dil Kurumu.

Cebecioğlu, Ethem (1997). Tasavvuf Terimleri ve Deyimleri Sözlüğü. Ankara: Rehber.

Çelebioğlu, Amil (1999). Türk Edebiyatı’nda Mesnevi (XV. Yy.'a Kadar), İstanbul: Kitabevi.

Demirli, Ekrem (2018). Şair Sûfiler Mevlana, Yunus Emre ve Niyazî-i Mısrî Üzerine İncelemeler. İstanbul: Sufi Kitap.

Devellioğlu, Ferit (2009). Osmanlıca-Türkçe Ansiklopedik Lûgat. Ankara: Aydın.

Dinî Kavramlar Sözlüğü. (Hazırlayan: İsmail Karagöz), (2017). Ankara: Diyanet İşleri Başkanlığı.

Erarslan, Kemal (1989). “Ahmed Yesevi”, Ankara: Türkiye Diyanet Vakfi İslam Ansiklopedisi, C. 2.

Güneş, Mustafa (2006). İznikli Eşrefoğlu Rûmî’nin Hayatı Eserleri ve Dîvânı. İstanbul: Sahhaflar Kitap Sarayl.

Güzel, Abdurrahman (2012). Dinî - Tasavvufi Türk Edebiyatı El Kitabı. Ankara: Akçağ.

http://lugatim.com/

https://hadislerleislam.diyanet.gov.tr/

https://sozluk.gov.tr/

İnalcık, Halil (çev. İbrahim Kalın) (2004). “İstanbul: Bir İslâm Şehri”. Marife. S. 2, s. 309-325.

Kanar, Mehmet (2011). Osmanlı Türkçesi Sözlüğü. İstanbul: Say.

Kara, Mustafa (2011). “Tekke”. Türkiye Diyanet Vakfi İslam Ansiklopedisi. C. 40.

Karasu, Büşra (2018). “15. Yüzyll Tekke Şiirinde Tasavvuf Terimleri”. Basılmamış Yüksek Lisans Tezi. İstanbul: İstanbul Üniversitesi.

\begin{tabular}{r|l} 
Adres & Address \\
RumeliDE Dil ve Edebiyat Araştırmaları Dergisi & RumeliDE Journal of Language and Literature Studies \\
Osmanağa Mahallesi, Mürver Çiçeği Sokak, No:14/8 & Osmanağa Mahallesi, Mürver Çiçeği Sokak, No:14/8 \\
Kadıköy - İSTANBUL / TÜRKIYE 34714 & Kadıköy - ISTANBUL / TURKEY 34714 \\
e-posta: editor@rumelide.com & e-mail: editor@rumelide.com, \\
tel: +90 505 7958124, +90 216773 o 616 & phone: +90 505 7958124, +90 216773 o 616
\end{tabular}


Kâşânî, Abdürrezzak (Çev: Ekrem Demirli) (2015). Tasavvuf Sözlüğü. İstanbul: İz.

Korkmaz, Zeynep (2009). Türkiye Türkçesi Grameri. Ankara: Türk Dil Kurumu.

Metinlerle Tasavvuf Terimleri Sözlüğü. (ed. Zafer Erginli) (2006). Trabzon: Kalem Yayınevi.

Mütercim Âsım Efendi. (haz: Mürsel Öztürk - Derya Örs) (2009). Burhân-ı Katı. Ankara: Türk Dil Kurumu.

Mütercim Âsım Efendi. (nşr. Mustafa Koç-Eyyüp Tanrıverdi). (2013-2014). El-Okyânûsu'l-Basît fi Tercemeti'l-Kâmûsu'l-Muhît. Türkiye Yazma Eserler Kurumu Başkanlığı. http://www.kamus.yek.gov.tr/

Öngören, Reşat (2010). “Şeyh”. Türkiye Diyanet Vakfi İslam Ansiklopedisi. C.39.

Pala, İskender (2018). Ansiklopedik Divan Şïri Sözlüğü. İstanbul: Kapı.

Parlatır, İsmail (2007). Atasözleri ve Deyimler. Ankara: Yargı.

Pehlivan, Elif (2001). "Nasihat-nâme Şeyh Eşref b. Ahmed”. Basılmamış Yüksek Lisans Tezi. İstanbul: Marmara Üniversitesi.

Pekolcay, Necla (1981). İslâmî Türk Edebiyatı 1. İstanbul: Dergâh.

Pekolcay, Necla (2016). Mevlid Süleyman Çelebi. İstanbul: Dergâh.

Sever, Mustafa (2016). Dîvân-ı Kaygusuz Abdal. Ankara: Helke.

Steingass, F. A. (1998). Comprehensive Persian-English Dictionary. Beirut, Lenanon.

Şemseddin Sami (2007). Kâmûs-ı Türkî. İstanbul: Çağrı.

Şentürk, Ahmet Atillâ (2015). "Manzum Metinler Işı̆̆ında Bir Kalender Dervişinin Profili”. Turkish Studies International Periodical For The Languages, Literature and History of Turkish or Turkic. Volume 10/8 Spring.

Şentürk, Ahmet Atillâ (2016). Osmanlı Şïri Kılavuzu 1. İstanbul: OSEDAM Osmanlı Edebiyatı Araştırmaları Merkezi.

Şimşek, Selami (2017). Tasavvuf Edebiyatı Terimleri Sözlüğü. İstanbul: Litera.

Tanman, M. Baha - Parlak, Sevgi (2011). “Tekke”. İstanbul: Türkiye Diyanet Vakfi İslam Ansiklopedisi. C. 40.

Tarih ve Edebiyat Metinleri Bağlaml Dizin ve İşlevsel Sözlüğ̈̈ (TEBDİZ).

Tavukçu, Orhan Kemal (2020). Dede Ömer Rûşenî Hayatı, Eserleri, Edebî Kişiliği ve Dîvânının Tenkidli Metni. Ankara: T. C. Kültür ve Turizm Bakanlı̆̆ Kütüphaneler ve Yayımlar Genel Müdürlüğü.

Topaloğlu, Bekir (1989). “Allah”. Türkiye Diyanet Vakfi İslam Ansiklopedisi. C. 2.

Türk, Vahit (1987). “Hatiboğlu'nun Bahrü’l-Hakayık'ı”. Yüksek Lisans Tezi. Ankara: Gazi Üniversitesi.

Uçar, İlhan (2010). "Türkçede Eş Anlamlılık ve Eski Anadolu Türkçesi Tıp Yazmalarında Eş Anlamlı Kelime Kullanımı”. Zeitschrift für die Welt der Türken Journal of World of Turks. Vol. 2, No.1.

Uludağ, Süleyman (2003). "Masiva”. Türkiye Diyanet Vakfi İslam Ansiklopedisi. C. 28.

Uludağ, Süleyman (2010). "Şürb”. Türkiye Diyanet Vakfi İslam Ansiklopedisi. C. 39.

Uludağ, Süleyman (2012). Tasavvuf Terimleri Sözlüğü. İstanbul: Kabalcı.

Uzun, Mustafa İsmet (2003). “Mecaz”. Türkiye Diyanet Vakfi İslam Ansiklopedisi. C. 28.

Yavuzer, Hayati (1997). Kemâl Ümmî Dîvânı İnceleme-Metin. Doktora Tezi. Ankara Gazi Üniversitesi.

Yavuzer, Hayati (2008). Kemâl Ümmî Dîvânı İnceleme - Metin. Bolu: Abant İzzet Baysal Üniversitesi Bolu Halk Kültürünü Araştırma ve Uygulama Merkezi: 3.

Yazıcı, Tahsin (1994). "Derviş”. Türkiye Diyanet Vakfi İslam Ansiklopedisi. C. 9.

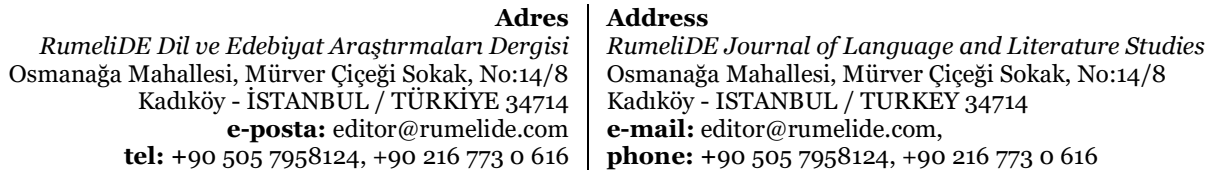


792 / RumeliDE Journal of Language and Literature Studies 2021.24 (September)

In the context of selected texts sample mystical idioms from 15th century Tekke poetry and the words and phrases that express the concepts of Allah, the world, the guide, the dervish, the divine love, the masiva, the lodge and the nafs / B. Karasu (pp. 771792

Yıldırımer, Mestan (2012). Gülşenî-i Saruhânî Râz-nâme (Makâlât-ı Gülşenî) Sirlar Kitabı. İstanbul: Büyüyenay.

Yllmaz, Mehmet (2013). Kültürümüzde Ayet ve Hadisler. İstanbul: Kesit. 